\title{
The future as a social fact. The analysis of perceptions of the future
}

\section{in sociology}

\author{
Jens Beckert, Lisa Suckert \\ Max Planck Institute for the Study of Societies, Cologne, Germany
}

\author{
MPIfG Journal Article \\ Jens Beckert, Lisa Suckert: The Future as a Social Fact: The Analysis of Perceptions of the Future in Sociology. In: Poetics (84), \\ 101499 (2021). Elsevier \\ The MPIfG Journal Articles series features articles by MPIfG researchers and visiting scholars published in peer-reviewed journals. \\ Max Planck Institute for the Study of Societies (MPIfG) Cologne | www.mpifg.de
}

\section{A R T I C L E I N F O}

\section{Keywords:}

Temporality

Future

Aspirations

Expectations

Sociology of time

Sociology of knowledge

\begin{abstract}
A B S T R A C T
A small but growing share of sociological research recognizes the importance of perceptions of the future for explaining social outcomes. This article, taking a sociology of knowledge perspective, provides a systematic study of sociological scholarship dealing empirically with perceptions of the future. It is based on a qualitatively driven mixed methods analysis of 571 sociological research articles published between 1950 and 2019 and distinguishes between three clusters of scholarship: in the first cluster authors consider future orientations as either dependent or independent variable; in the second cluster they analyze the multifaceted ways in which actors imagine the future; and in the third cluster they are interested in the politically contested construction and diffusion of future orientations. By investigating these clusters, the article demonstrates how sociologists pay attention to future orientations in a broad spectrum of sociological fields, using a variety of methods and asking a wide set of questions about assessments of the future. The future is increasingly a realm of sociological analysis. We show how this field of research is structured and has developed over time. Elaborating on different facets of research that so far operate largely in isolation from each other, we aim to contribute to the development of the field. Sociology could benefit from more systematically integrating perceptions of the future - as they are reflected in actor expectations, aspirations, and future beliefs - into the discipline's empirical investigations and explanatory models and from integrating the existing knowledge on these issues better.
\end{abstract}

\section{Introduction}

Sociology as a discipline is primarily directed toward the present and past. Phenomena observed in the present are seen as being causally linked to events that have taken place at an earlier point in time. They are shaped by cultures, institutions or social relations that exist in the present but have been formed in the past.

A much smaller part of sociology, however, breaks with this dominant temporal perspective and considers actor orientations toward the future. This break follows two lines of inquiry. First, in so called "future studies" sociologists have projected possible future developments and investigated how desired or feared states could be achieved or prevented (Adam \& Groves, 2007; Bell, 1973; for an overview see Andersson, 2018). Second, the future orientation of actors itself has been studied as an object of sociological inquiry. This second approach proceeds from an understanding of perceptions of the future as a social fact: future orientations are seen as causal factors influencing social outcomes.

In this article, we focus on the second line of inquiry. How have sociologists worked empirically with perceptions of the future and

\footnotetext{
* Corresponding author.

E-mail addresses: beckert@mpifg.de (J. Beckert), suckert@mpifg.de (L. Suckert).
} 
analyzed them as social facts? We set out to explore this small but expanding research strand from a sociology of knowledge perspective. Based on a qualitatively driven mixed methods analysis of 571 English language research articles we map the emergence and historical development of the field during the last seven decades. Capturing the main research topics, theoretical frameworks and methodological approaches, we show how knowledge about future perceptions is produced and what internal divisions govern this research field.

Complementing qualitative content analysis with elements of cluster and principal component analysis, we can show that the field of sociological research concerned with future orientations emerged from a relatively homogenous core in the 1950s and 1960s, and developed into a research field currently structured by three discernable clusters: the first one studies the future as a variable; the second is interested in what imaginaries of the future look like; and the third considers the contested processes in which future perceptions are constructed. The analysis indicates that these research clusters not only differ in their epistemological approaches but have also emerged at different points in time, were influenced by different sociological traditions and use different journals as outputs of their research.

Our comprehensive assessment of studies that analyze the future as a social fact contributes to the development of this diversified sociological research field by investigating its respective perspectives, potentials and lacunae. It emphasizes how sociology could benefit from more prominently integrating perceptions of the future into the discipline's empirical investigations and explanatory models.

Following a brief discussion of the role of future orientations in sociological theory, the third section presents the text corpus and the qualitatively driven mixed methods approach our study is based on. It is complemented by an appendix detailing the corpus selection process. The next two sections show how the research field has emerged and grown since the 1950s and diversified across sociological subfields and subjects particularly since the 1990s. Sections six and seven take stock of the epistemological structure of the field; three research clusters adopting divergent approaches to study the future as a social fact are identified and described in detail. Section eight shows how these clusters have diversified over time and provides explanations for these developments. The various journals in which sociological research on future perceptions is predominantly published are explored in section nine. In the conclusion we summarize our findings and discuss several lacunae and future research paths which our analysis indicates.

\section{The future in sociology}

Social science disciplines differ in their temporal orientations. Sociology, as well as anthropology and political science, is a discipline whose explanatory models are primarily rooted in the past and the present. An outcome is explained by previous events, leading causally to what is being observed in the present. Statistical models use information from the past to explain observed phenomena and to predict future developments. Alternatively, outcomes are explained by present social structures such as social networks or social norms.

Sociology's dominant temporal orientation on the past and the present contrasts remarkably with the temporal perspective in economics, but also to an extent in psychology. As Andrew Abbott puts it succinctly: "While sociologists see present events as a final outcome emerging from the past, economists reason backwards from the future: Decisions are explained by the present value of expected future rewards" (Abbott, 2005, p. 406).

This does not imply that the temporal orientation toward the future has not played any role in sociology. To the contrary, a closer look shows a rich tradition of this. Max Weber's Protestant Ethics (2002) sees future expectations of salvation as causally influencing the conduct of life. Later, theoretical work, in particular that rooted in the phenomenological tradition and in American Pragmatism, showed sensitivity for the relevance of the future orientation of actors. ${ }^{1}$ This probably comes to the fore most clearly in the work of Alfred Schutz, who asserts that courses of action are chosen by "projecting", which "consists in anticipation of future conduct by way of phantasying" (Schutz, 1972, p. 20, see also Beckert, 2016). Before engaging in the actual activity of attempting to realize a goal, an actor creates a fantasy of himself "at a future time, when this action will already have been accomplished" (ibid.). In this sense, projects are "anticipated in the Future Perfect Tense" (Schutz, 1972, p. 20). The phenomenological understanding of action as future oriented has strongly influenced the work of Pierre Bourdieu (1979), Harold Garfinkel (1967), Berger and Luckmann (1991), Anthony Giddens (1994), and Niklas Luhmann (1976). It has equally influenced the new sociological institutionalism (DiMaggio \& Powell, 1983; Meyer \& Rowan, 1977). American pragmatists developed a notion of action which focuses on the present, but sees present action as informed by perceptions of the future and the past (Mead, 1932; Iddo Tavory, 2018). John Dewey describes action as anchored in "ends-in-view", which he defines as "foreseen consequences which influence present deliberation" (Dewey, 1957, p. 223). Emirbayer and Mische (1998), in their well-known treatment of "agency", in which they also stress the future orientation of action, refer primarily to the phenomenological and the pragmatist traditions. ${ }^{2}$

The sociology of time is another important, partly overlapping, strand of sociological scholarship that addresses the future (Bergmann, 1992; Hassard, 1990; Zerubavel, 1981). Mainly referring back to Emile Durkheim's claim to consider time as a social fact (Durkheim, 2001, 10ff), scholars start from the premise that social relations are inherently organized and governed by time, but the perception of time - also referred to as temporality - is the result of social construction (Abbott, 2001; Adam, 2013; Sorokin \& Merton, 1937). In this reasoning, the future features as an important temporal sphere alongside to the present and the past (Flaherty \& Fine,

\footnotetext{
${ }^{1}$ Other sociological works in which the future orientation of actors plays a crucial role are Robert Merton's (1957) strain theory and Albert Hirschman's (1963; 1971) possibilism. For the latter see also Lepenies (2008).

${ }^{2}$ See also Mische (2009; 2014), Wagner-Pacifici (2009), Strauss (1993).
} 
2001). Scholars like Iddo Tavory (2018; with Eliasoph, 2013) or Ann Mische (2009; 2014) have pursued theoretical frameworks dedicated more explicitly to the future. The future also plays a role for sociologists of time who are interested in the transition from more traditional perceptions of time to modern temporalities (Bourdieu, 1979; Elias, 2007; Nowotny, 1994; Simmel, 1978, p. 499f). Often drawing on Koselleck's historical work, the idea of progress is considered to be enshrined in many social institutions originating in the Enlightenment era (Wagner, 2016). Progress is seen as requiring a new, linear understanding of time, in which actors depart from an unfavorable past towards an open and shapeable future. Along the same lines, the norm of future-orientation is also considered a crucial element of capitalist time regimes (Beckert, 2016; Sewell, 2008) and particularly drives temporalities of acceleration (Rosa, 2013; Wajcman, 2015; Wajcman \& Dodd, 2016).

Without doubt, the future orientation of actors has been a concern in sociological theory. But to what extent do perceptions of the future enter into empirical work in sociology? How have sociologists studied perceptions of the future as a social fact?

\section{Mapping the development of a research field: data and methods}

To answer these questions, we explore sociological articles that empirically investigate perceptions of the future. Our analysis maps this field from a sociology of knowledge perspective by making apparent the historical development of the field, its main research topics and methodological approaches, its internal divisions, its connections to societal shifts and to substantial research fields in sociology, and its location within the arenas of sociological deliberation, operationalized as the main academic journals used for research output.

Our study of the research field uses a qualitatively driven mixed methods approach (Hesse-Biber, Rodriguez, \& Frost, 2015). Despite major advances in quantitative text analysis, we believe that a study concerned with the assessment of knowledge can best be achieved with a combination of a qualitative and quantitative approaches. Knowledge cannot be reduced to word frequencies or co-occurrences, and understanding the "sense making" of researchers requires reflexive, human interpretation. This is even more true when we seek to discern the evolution of knowledge over time (Hamann \& Suckert, 2018). Therefore, reading, understanding and discussing the 571 research articles this study draws on has been a main component of our analysis.

The major qualitative research steps of the study, i.e. the selection of relevant articles (see appendix), the development of appropriate categories, the coding of content and the interpretation of quantitative results were all conducted with a consensual approach (Kuckartz, 2014, p. 74f). Research choices, doubts and reflections were written down in memos while ambiguous cases were discussed by at least two researchers in order to produce intersubjectively intelligible interpretations. It is this qualitative assessment that allowed us to make sense of the research field and identify relevant types of studies and developments in the first place. Yet, we have complemented and substantiated these qualitative insights with some quantitative, or quantifying tools, which will be specified below. Drawing on quantifying methods such as cluster and principal component analysis enabled us to systematically compare across our extensive text corpus, to challenge and generalize our qualitatively derived insights and finally to visualize our findings in a comprehensive manner.

This qualitatively driven mixed methods approach was applied to the sample of 571 research articles ${ }^{3}$ which met the following criteria: We looked for (a) sociological, ${ }^{4}$ (b) English language articles, which were (c) published between 1950 and 2019 , were (d) concerned with future orientations and (e) studied them empirically. Based on these criteria the corpus was assembled by four complementary strategies of literature search: first a comprehensive search in the sociology category of the Web of Science database; second, an additional search in leading sociological journals for the years 1950-2019; third, a search for sociological articles within more interdisciplinary outlets; and fourth, a traditional literature search starting from bibliographies and discussions with experts in the field. These complementary strategies as well as their limitations are described in detail in the appendix.

In the remainder of the article we present the analyses and findings. Further methodological details on particular research steps are provided in the respective sections. In the course of our study, we will highlight several research articles from our text corpus to make the different approaches within the research field more visible and provide a more vivid account of the research field under study. The choice of these exemplary articles is based on cluster analysis but remains subjective in the sense that we discuss articles which we consider especially well suited to describe typical research within the cluster.

\section{Emergence and growth of the research field}

The sociological research field under scrutiny emerged in the 1960s. By this time, and building on pioneering work already published in the 1950s, modern post-war sociology was increasingly discovering future orientations as an empirical object of investigation.

Fig. 1 displays the 571 articles of our text corpus according to their year of publication as well as the 3-year moving average. It shows that the emergence and subsequent growth of the field has not been linear. Instead, two different upswings of research interest can be distinguished. We can see that articles concerned with future orientations first peaked during the 1960s and early 1970 s, were

\footnotetext{
${ }^{3}$ A bibliography of the 571 articles that constitute our text corpus is available online (Suckert, Beckert, \& Fenkner, 2020)

${ }^{4}$ An article qualified as "sociological", if at least one of the following was true: The article is assigned to WOS category "sociology"; the authors' affiliation refers to sociology (e.g. chair of sociology); the authors' webpage refers to sociology (self-description, research interests, degrees); the article claims to be sociological or positions itself within sociological literature; the article has at least five citations of clearly sociological literature (sociological canon or classical sociological journals); the main argument of the article refers to "the social" and adopts key sociological concepts.
} 


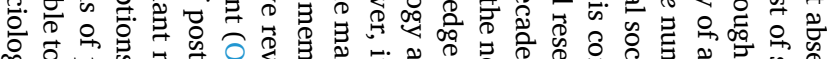

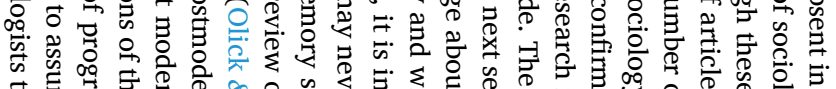

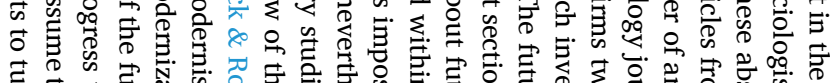

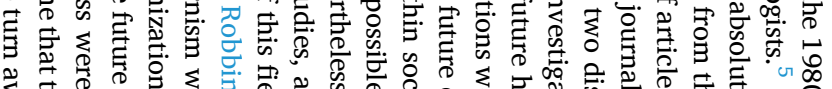

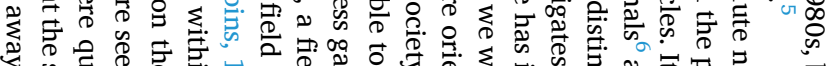

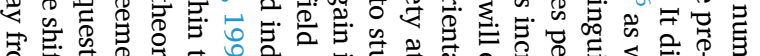

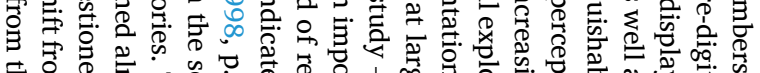

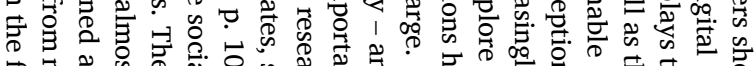

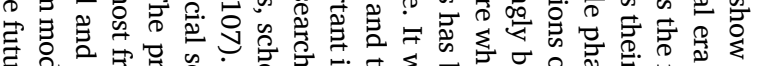

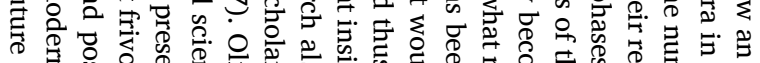
Ð

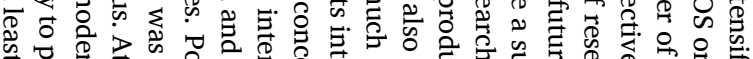

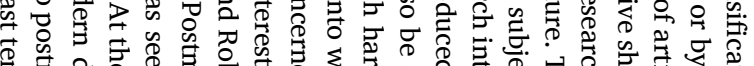

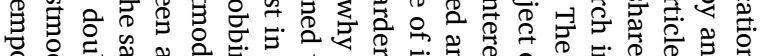

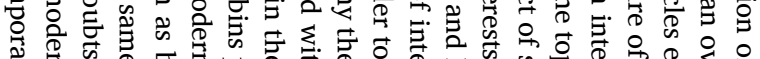

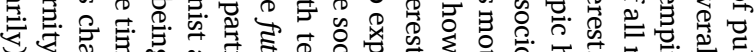

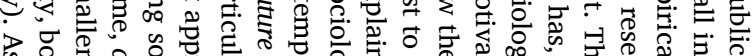

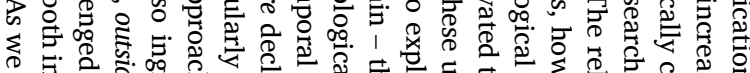

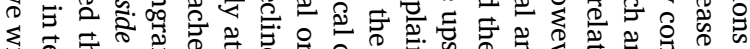

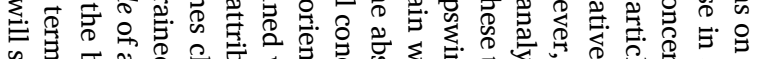

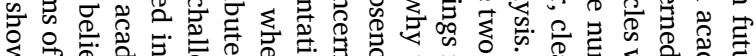

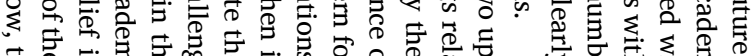

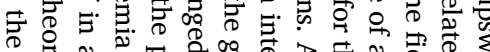

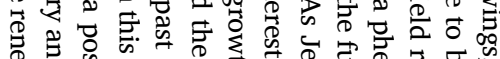

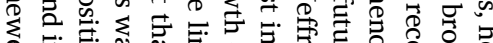

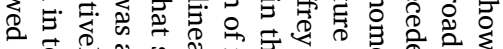

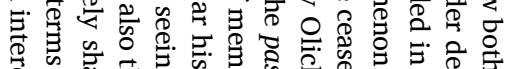
过总

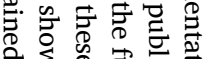

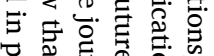

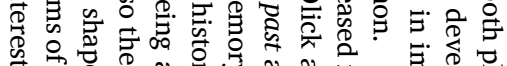

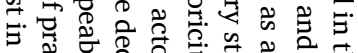
등

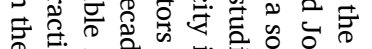

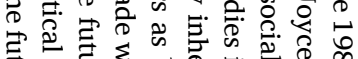

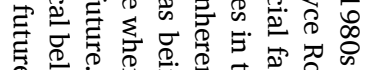

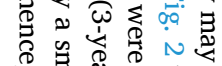

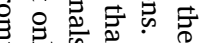

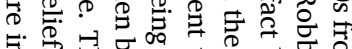
究 क क्र

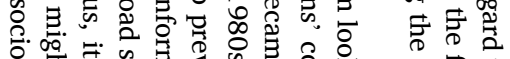
을 달 응

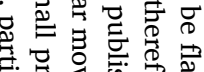

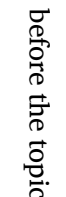

西

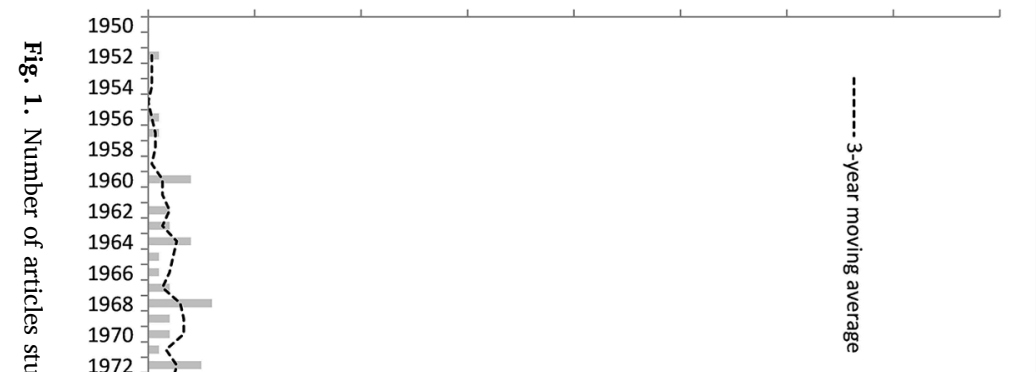
Mำ

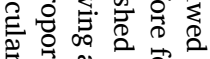

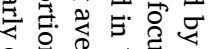

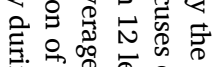
(5.

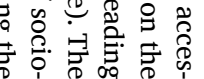

.




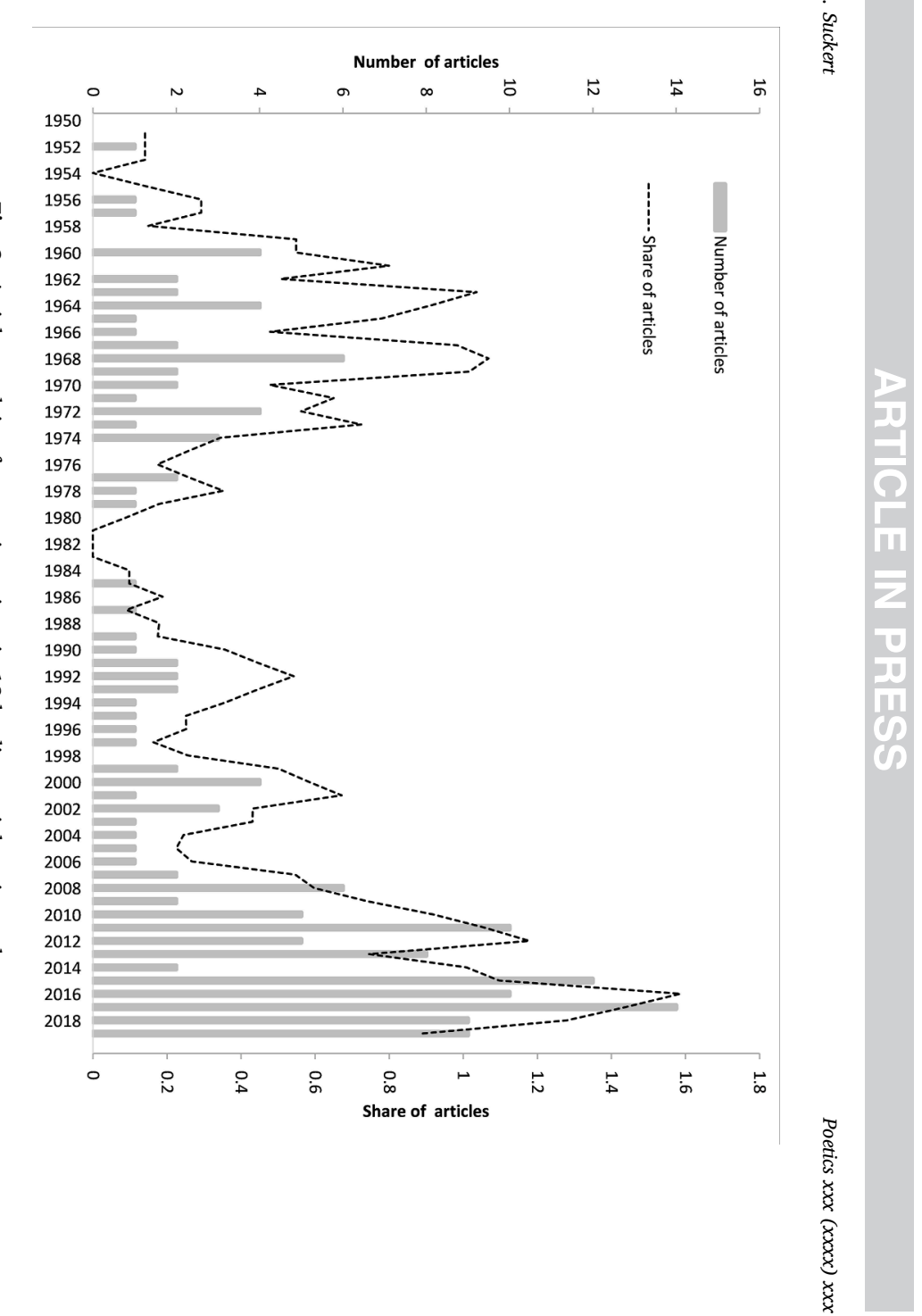




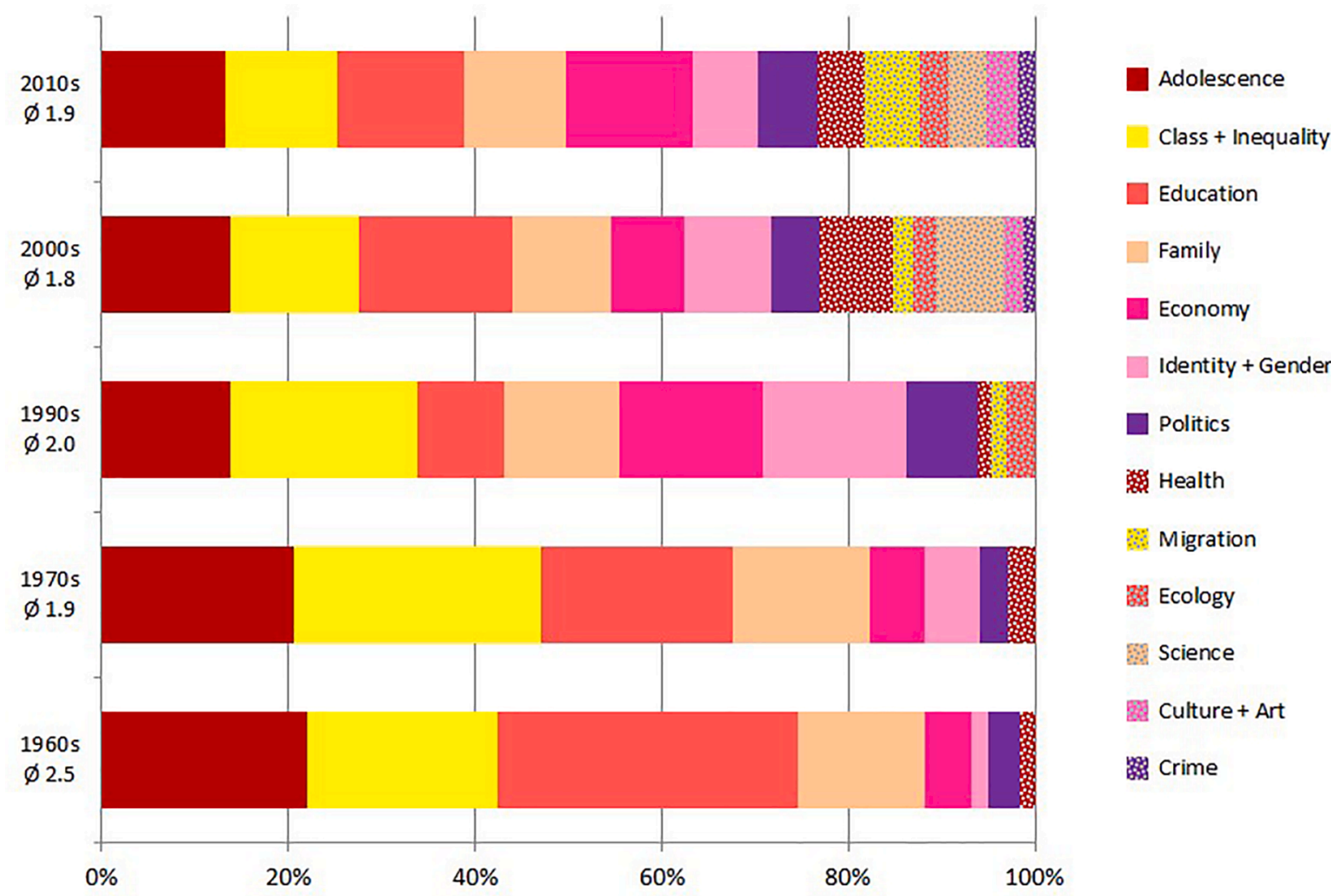

Fig. 3. Sociological subfields interested in future orientations: Share of assigned areas per decade $(\varnothing=$ average number of areas assigned per article).

of the future? (2) How did they analyze the captured perceptions of the future? (3) In what features of the perceived future were the researchers particularly interested? The respective responses indicate how empirical knowledge about future perceptions is produced. We therefore used methods of inquiry (1), methods of analysis (2) and features of interest (3) as the three basic variables to assess and analyze the epistemological structure of the research field. Abstracting from concrete answers to the above questions, we iteratively developed a set of categories for each of these variables. Table 1 gives an overview of all adopted categories, providing a description used for coding, an exemplary study and the share of articles coded for respective categories.

For methods of inquiry and analysis, i.e. how to first capture future orientations and then how to explore these captured orientations, the development of categories and the subsequent coding were rather straight forward. As both variables refer to methodological choices inherent to any empirical study, they were often made explicit in the texts. Moreover, we could draw on established methodological typologies to define and assign appropriate categories. The task here was to iteratively summarize and establish a rather concise set of categories for each variable. As a matter of fact, none of the methods categories we developed are mutually exclusive. Some researchers have gathered data by combining, e.g. stimuli and ethnographic observation or by using focus groups that integrated elements of conventional interviews. Moreover, a few researchers have opted for mixed methods approaches, combining qualitative and quantitative modes of analysis. Therefore, each article of our corpus was coded with at least one category for method of inquiry and one category for method of analysis, but often with more than one of these categories.

In contrast, defining categories that described the features scholars concerned with future orientations were interested in proved much harder. Here, we could not draw on existing typologies. Ann Mische's (2014) instructive theoretical framework served as a point of departure but the 17 features described in Table 1 were developed in an inductive and iterative process. Again, we discussed ambiguous cases and readapted coding descriptions to establish intersubjectively intelligible interpretations.

The variety of features scholars have been interested in when studying future orientations illustrates the variety of epistemological perspectives within the field. Some features focus on the content of future perceptions (e.g. actors involved in the future), while others look out for the underlying logics (e.g. temporal configuration) or the context in which future perceptions are generated (e.g. construction process). Some features assume a rather static world (e.g. effects on future orientations), while others explicitly refer to a dynamic (e.g. (in)stability of the future) or even a contingent (e.g. contingency of the future) world. Overall, some features point to rather positivistic perspectives (e.g. effects of future orientations), while others imply constructivist (e.g. future based identity) or interactionist and pragmatist (e.g. politics of the future) approaches. 
Table 1.

How have researchers studied perceptions of the future? Adopted categories.

\begin{tabular}{|c|c|c|c|}
\hline & $\begin{array}{l}\text { Categories } \\
\text { (\% of corpus) }\end{array}$ & Description & Exemplary Study \\
\hline \multirow[t]{6}{*}{$\begin{array}{l}\text { Method of } \\
\text { inquiry }\end{array}$} & $\begin{array}{l}\text { Survey } \\
(35.73 \%)\end{array}$ & $\begin{array}{l}\text { investigation by written, electronic or oral } \\
\text { questionnaire }\end{array}$ & $\begin{array}{l}\text { Feliciano and Rumbaut (2005) use longitudinal survey to } \\
\text { investigate changing aspirations of immigrant children. }\end{array}$ \\
\hline & $\begin{array}{l}\text { Interview } \\
(49.56 \%)\end{array}$ & $\begin{array}{l}\text { oral interaction with series of open-ended } \\
\text { questions }\end{array}$ & $\begin{array}{l}\text { Gonzales (2011) interviews youths without residency documents in } \\
\text { the US about their shattered future aspirations. }\end{array}$ \\
\hline & $\begin{array}{l}\text { Focus group } \\
(4.38 \%)\end{array}$ & a group is asked to discuss open-ended questions & $\begin{array}{l}\text { Ylijoki and Mäntylä (2003) employ focus groups to account for the } \\
\text { conflicting future expectations of precarious researchers. }\end{array}$ \\
\hline & $\begin{array}{l}\text { Task and stimulus } \\
(5.25 \%)\end{array}$ & $\begin{array}{l}\text { an exercise is assigned to respondents, often by } \\
\text { exposing them to material objects as stimuli }\end{array}$ & $\begin{array}{l}\text { Coleman (2008) asks teenage girls to create collages of their future } \\
\text { bodies using craft materials, thus enabling them to visualize what } \\
\text { might change or stay the same in years to come. }\end{array}$ \\
\hline & $\begin{array}{l}\text { Ethnographic } \\
\text { observation } \\
(12.96 \%)\end{array}$ & $\begin{array}{l}\text { detailed observation of actors within their social } \\
\text { setting }\end{array}$ & $\begin{array}{l}\text { Ybema (2010) participated in the everyday working life of the } \\
\text { editorial staff to explore how future orientations played into the } \\
\text { organizational identity of a newspaper. }\end{array}$ \\
\hline & $\begin{array}{l}\text { Document research } \\
(17.51 \%)\end{array}$ & analysis of verbalized sources and artifacts & $\begin{array}{l}\text { Jasanoff and Kim (2009) analyze political speeches, government } \\
\text { reports, and court cases to show how the future of nuclear power is } \\
\text { imagined in South Korea and the US. }\end{array}$ \\
\hline \multirow[t]{2}{*}{$\begin{array}{l}\text { Method of } \\
\text { analysis }\end{array}$} & $\begin{array}{l}\text { Quantitative } \\
\text { (47.81\%) }\end{array}$ & $\begin{array}{l}\text { investigating and measuring numerical data by } \\
\text { statistical, mathematical, or computational } \\
\text { instruments }\end{array}$ & $\begin{array}{l}\text { Karlson (2019) analyzes survey data by linear regression models to } \\
\text { test whether disadvantaged students are more likely to revise } \\
\text { educational expectations due to their changing performance at } \\
\text { school. }\end{array}$ \\
\hline & $\begin{array}{l}\text { Qualitative } \\
(55.17 \%)\end{array}$ & $\begin{array}{l}\text { investigating and understanding non-numerical } \\
\text { data }\end{array}$ & $\begin{array}{l}\text { Andersson (2014) uses Dutch and Swedish reports for a historical } \\
\text { case study that shows how the "long term" future became a concern } \\
\text { for policy makers. }\end{array}$ \\
\hline \multirow[t]{14}{*}{$\begin{array}{r}\text { Features of } \\
\text { interest }\end{array}$} & $\begin{array}{l}\text { Effect of future } \\
\text { orientations } \\
(23.47 \%)\end{array}$ & $\begin{array}{l}\text { future perceptions considered as dependent } \\
\text { variable, i.e. what factors have an impact on the } \\
\text { way the future is imagined }\end{array}$ & $\begin{array}{l}\text { Duncan et al. (1968) analyze how peer groups affect young peoples' } \\
\text { aspirations. }\end{array}$ \\
\hline & $\begin{array}{l}\text { Effect on future } \\
\text { orientations } \\
(36.78 \%)\end{array}$ & $\begin{array}{l}\text { future perceptions considered as independent } \\
\text { variable, i.e. what impact has the imagined } \\
\text { future on other factors }\end{array}$ & $\begin{array}{l}\text { Marini and Fan (1997) show that differences in occupational } \\
\text { aspirations are the most important effect explaining gender wage } \\
\text { differences. }\end{array}$ \\
\hline & $\begin{array}{l}\text { Future time horizon } \\
(16.81 \%)\end{array}$ & $\begin{array}{l}\text { how far (e.g. months, years, decades) } \\
\text { perceptions reach into the future }\end{array}$ & $\begin{array}{l}\text { Brannen \& Nilsen, } 2002 \text { find that while less qualified women } \\
\text { oriented themselves towards an extended present, well qualified } \\
\text { males even considered the long distant future predictable. }\end{array}$ \\
\hline & $\begin{array}{l}\text { Temporal } \\
\text { configuration of the } \\
\text { future } \\
(6.48 \%)\end{array}$ & $\begin{array}{l}\text { whether future orientations are based on specific } \\
\text { ideas about the progression of time, like e.g. } \\
\text { linear or cyclical time }\end{array}$ & $\begin{array}{l}\text { Reith (1999) finds that the experience of addiction is characterized } \\
\text { by the inability to imagine the future and thus "lost time", while } \\
\text { recovery is experienced as regaining a linear perception of time, } \\
\text { geared towards the future. }\end{array}$ \\
\hline & $\begin{array}{l}\text { Stability of future } \\
\text { orientations } \\
(10.33 \%)\end{array}$ & $\begin{array}{l}\text { whether and how perceptions of the future } \\
\text { change over time }\end{array}$ & $\begin{array}{l}\text { Hanson (1994) observes that students from lower social } \\
\text { backgrounds often reduced their high aspirations during early } \\
\text { adolescence. }\end{array}$ \\
\hline & $\begin{array}{l}\text { Storyline towards the } \\
\text { future } \\
(24.34 \%)\end{array}$ & $\begin{array}{l}\text { whether and how actors imagine the path from } \\
\text { the present to the future }\end{array}$ & $\begin{array}{l}\text { Boje (1991) shows how organizations make sense of their situation } \\
\text { by linking their present to their organizational future and putting } \\
\text { forward competing storylines. }\end{array}$ \\
\hline & $\begin{array}{l}\text { Details of perceived } \\
\text { future } \\
(4.90 \%)\end{array}$ & $\begin{array}{l}\text { the varying extent of clarity and detailedness of } \\
\text { imagined futures }\end{array}$ & $\begin{array}{l}\text { Devadason (2008) finds that young Brits displayed very detailed, } \\
\text { employment-centered plans while young Swedes almost refused to } \\
\text { plan their future and insisted on living spontaneously. }\end{array}$ \\
\hline & $\begin{array}{l}\text { Contingency of the } \\
\text { future } \\
(18.39 \%)\end{array}$ & $\begin{array}{l}\text { whether actors consider the future as determined } \\
\text { or entailing multiple scenarios, as fixed, as } \\
\text { uncertain or as open }\end{array}$ & $\begin{array}{l}\text { Boyle and Haggerty (2012) show that hosts of Olympic Games deal } \\
\text { with the uncertainty of terrorist attacks by mapping out all possible } \\
\text { scenarios instead of predicting what is probable. }\end{array}$ \\
\hline & $\begin{array}{l}\text { Plurality of future } \\
\text { orientations } \\
(13.31 \%)\end{array}$ & $\begin{array}{l}\text { whether multiple and sometimes contrasting } \\
\text { visions of the future co-exist within the same } \\
\text { context }\end{array}$ & $\begin{array}{l}\text { Kaplan and Orlikowski's (2013) ethnographic study of a } \\
\text { manufacturer affected by crisis reveals a multitude of future } \\
\text { projections within the same organization. }\end{array}$ \\
\hline & $\begin{array}{l}\text { Politics of expectations } \\
(11.91 \%)\end{array}$ & $\begin{array}{l}\text { whether and how future expectations serve as } \\
\text { contested means of domination }\end{array}$ & $\begin{array}{l}\text { Yilmaz (2012) reveals how far right movements succeeded in } \\
\text { presenting Muslim immigrants as a threat to the future of European } \\
\text { culture and population. }\end{array}$ \\
\hline & $\begin{array}{l}\text { Construction process of } \\
\text { future orientations } \\
(8.41 \%)\end{array}$ & $\begin{array}{l}\text { what processes the future is constructed in, } \\
\text { including respective discourses, interactions and } \\
\text { tools }\end{array}$ & $\begin{array}{l}\text { Bakker et al. (2011) describe how expectations about new hydrogen } \\
\text { storage are constructed by interaction of different actor groups. }\end{array}$ \\
\hline & $\begin{array}{l}\text { Actors involved in the } \\
\text { future } \\
(25.39 \%)\end{array}$ & $\begin{array}{l}\text { who, i.e. what individuals or collectives are part } \\
\text { of the imagined future, and who is not }\end{array}$ & $\begin{array}{l}\text { Baldwin (2017) relates the practice of egg freezing to women's } \\
\text { expectations about the 'right' future partner or lack thereof. }\end{array}$ \\
\hline & $\begin{array}{l}\text { Agency about the } \\
\text { future } \\
(17.51 \%)\end{array}$ & $\begin{array}{l}\text { extent to which actors believe the future is a } \\
\text { consequence of their action, not destined by } \\
\text { some uncontrollable force }\end{array}$ & $\begin{array}{l}\text { Costas and Grey (2014) elucidate how power regimes within } \\
\text { management consultancies involve an extreme belief in the ability } \\
\text { of improving one's future self. }\end{array}$ \\
\hline & $\begin{array}{l}\text { Evaluation of the } \\
\text { future } \\
(26.27 \%)\end{array}$ & $\begin{array}{l}\text { whether the future is imagined as positive or } \\
\text { negative, promoting optimism or pessimism }\end{array}$ & $\begin{array}{l}\text { Kao (2000) shows how Black and Hispanic students pessimistically } \\
\text { try to avoid the negative future prevalently assigned to them, Asian } \\
\text { students want to optimistically keep up with the positive } \\
\text { expectations ascribed to them. }\end{array}$ \\
\hline
\end{tabular}


Table 1. (continued)

\begin{tabular}{|c|c|c|}
\hline $\begin{array}{l}\text { Categories } \\
\text { (\% of corpus) }\end{array}$ & Description & Exemplary Study \\
\hline $\begin{array}{l}\text { Normativity of future } \\
\text { orientations } \\
(12.08 \%)\end{array}$ & $\begin{array}{l}\text { whether future expectations are linked to a } \\
\text { moral argument or involve a normative } \\
\text { dimension }\end{array}$ & $\begin{array}{l}\text { Smith (2017) shows how ambitious educational and professional } \\
\text { aspirations serve as moral assertions for former foster youths. }\end{array}$ \\
\hline $\begin{array}{l}\text { Futurebased identity } \\
(20.14 \%)\end{array}$ & $\begin{array}{l}\text { whether imagined futures are driven by } \\
\text { perceptions of the (future)-self and thus a major } \\
\text { part of identity construction }\end{array}$ & $\begin{array}{l}\text { Frye (2012) portrays how, despite their unfavorable situations, } \\
\text { Malawi girls consider themselves as "those who aspire". }\end{array}$ \\
\hline $\begin{array}{l}\text { Space of the future } \\
(6.48 \%)\end{array}$ & $\begin{array}{l}\text { whether the future is associated with a particular } \\
\text { geographical location or venue }\end{array}$ & $\begin{array}{l}\text { Cuzzocrea (2018) assesses where students aspire to move by inviting } \\
\text { them to imagine themselves as being } 90 \text { and narrating their lives } \\
\text { backwards. }\end{array}$ \\
\hline
\end{tabular}

Altogether, the categories we developed depict a research field in which multiple epistemological approaches of studying future perceptions co-exist. The next sections will further explore the structure of this field and systematically depict its development across time.

\section{Studying the future as a social fact: A three-clustered research field}

Do particular methods of inquiry correspond with particular methods of analysis or features of interest? Can we thus distinguish different modes of knowledge production about future orientations? To explore the inherent structure of the research field, we complemented the previous qualitative analysis with cluster analytical tools. Cluster analysis basically establishes groups by assorting similar items, allowing researchers to discover different types of items within their sample. In the context of our study and based on our qualitative coding of articles, cluster analysis helped to differentiate distinctive modes of studying the future within the research field.

The coded characteristics (method of inquiry, method of analysis and features of interest, see Table 1) for each of the 571 articles were transferred to binary data ${ }^{9}$ and subsequently standardized for each of the three variables. As is suitable for originally categorical variables, Jaccard distances were used to account for similarity or difference of articles and a hierarchical cluster analysis (Ward method) was conducted.

Choosing the appropriate number of clusters is a critical and always interpretative step in any cluster analysis. Considering to what extent a higher number of clusters further reduces heterogeneity within clusters provides a first orientation. ${ }^{10}$ Based on both this quantitative assessment and the insights of our qualitative exploration - and with the aim of establishing a concise typology - we opted for a three-cluster solution.

In order to graphically visualize these three clusters, we conducted a complementary principal component analysis (PCA) on the same dataset. ${ }^{11}$ Fig. 4 displays the results of this analysis, with the different shades indicating the three distinctive clusters of articles, whereas the position of each article is based on the first two dimensions of the PCA. ${ }^{12}$ The graph reveals the distribution and scope of the three main clusters of research we distinguish in this study.

But how can these three clusters be characterized? Fig. 5 provides first evidence by displaying how the categories of our three active variables contribute to the two dimensions of the PCA. The graph implies that articles in cluster 1 , to the left of the plane, are mostly interested in future orientations as either dependent or independent variable, they use surveys to inquire future perceptions and adopt quantitative modes of analysis; articles in cluster 2, to the upper right, analyze the multifaceted ways in which actors imagine the future referring to various features, they inquire these imaginaries through interview related methods and analyze them qualitatively; studies in cluster 3, to the lower right, use qualitative methods of analysis too, but they capture respective future perceptions by document research and are concerned with the politically contested construction and plurality of future orientations.

In addition to exploring which methods of inquiry, methods of analysis and features of interest are characteristic for each cluster, PCA also enables us to depict what objects of investigation, discussed in section five of this article, relate to the three clusters. To this end we used the 13 categories we developed for areas of study as a passive variable. ${ }^{13}$ Fig. 6 indicates to which cluster respective areas of study correspond. We see that studies in cluster 1 mostly make education, adolescence, family and class their objects of investigations; cluster 2 articles are more concerned with identity, migration and health; studies in cluster 3 can be found in sociological subfields dedicated to ecology, politics, science and, to a lesser degree, the economy.

Though this quantitative assessment gives us an approximate idea of each cluster, it provides at best a superficial account of how

\footnotetext{
${ }^{9}$ i.e. whether an article was assigned to a specific category (1) or not (0);

10 The quantitative assessment indicated that three-cluster, five-cluster, six- and seven-cluster solutions would be viable options, but that a higher number of clusters did not extensively reduce heterogeneity.

${ }^{11}$ Based on singular value decomposition, PCA allows representing a dataset by reduced dimensionality. It is often used as exploratory instrument and to visualize distances between items on two dimensions.

${ }^{12}$ Cluster analysis and PCA were conducted in R with the packages vegan (Oksanen, Kindt, Legendre, O'Hara, \& Stevens, 2007) and factoMineR (Lê, Josse, \& Husson, 2008).

${ }^{13}$ Again, this originally categorial variable was transformed to binary, standardized data. Though PCA allows including categorial passive variables too, we used this variable as passive quantitative variables, because each article could be assigned to more than one area of study, which can only be represented by binary data.
} 


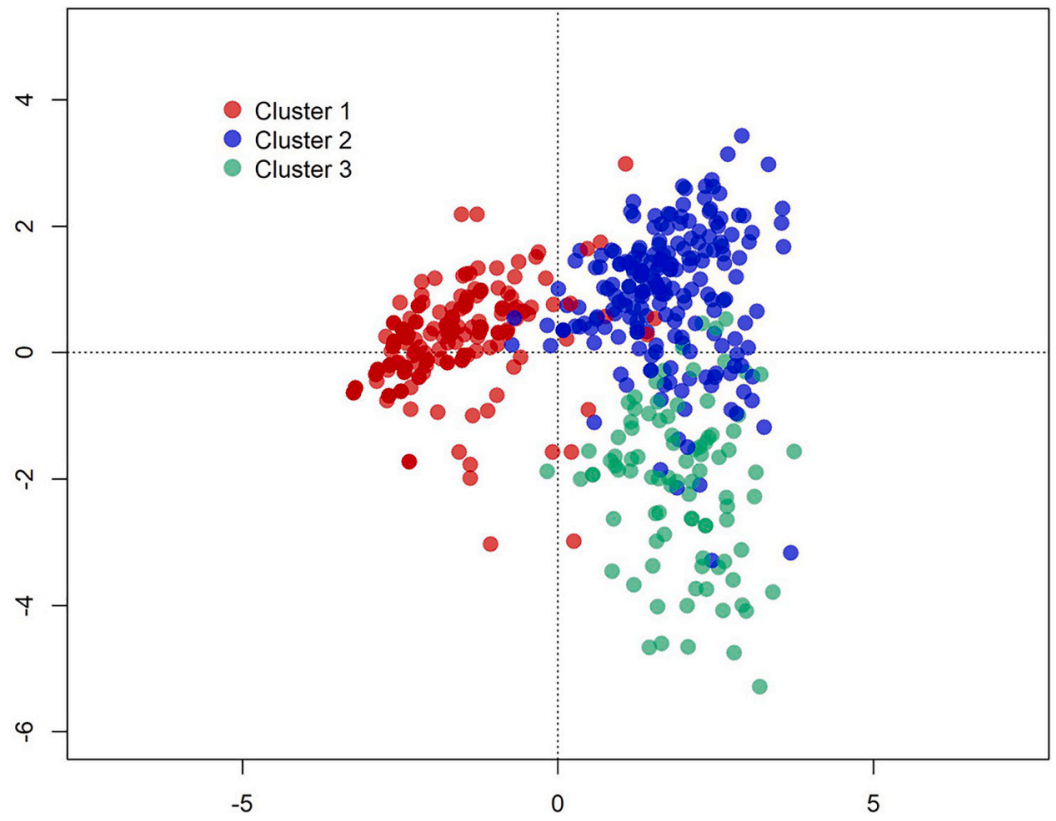

Fig. 4. Three clusters of empirical studies on future orientations, axes represent first two dimensions of PCA.

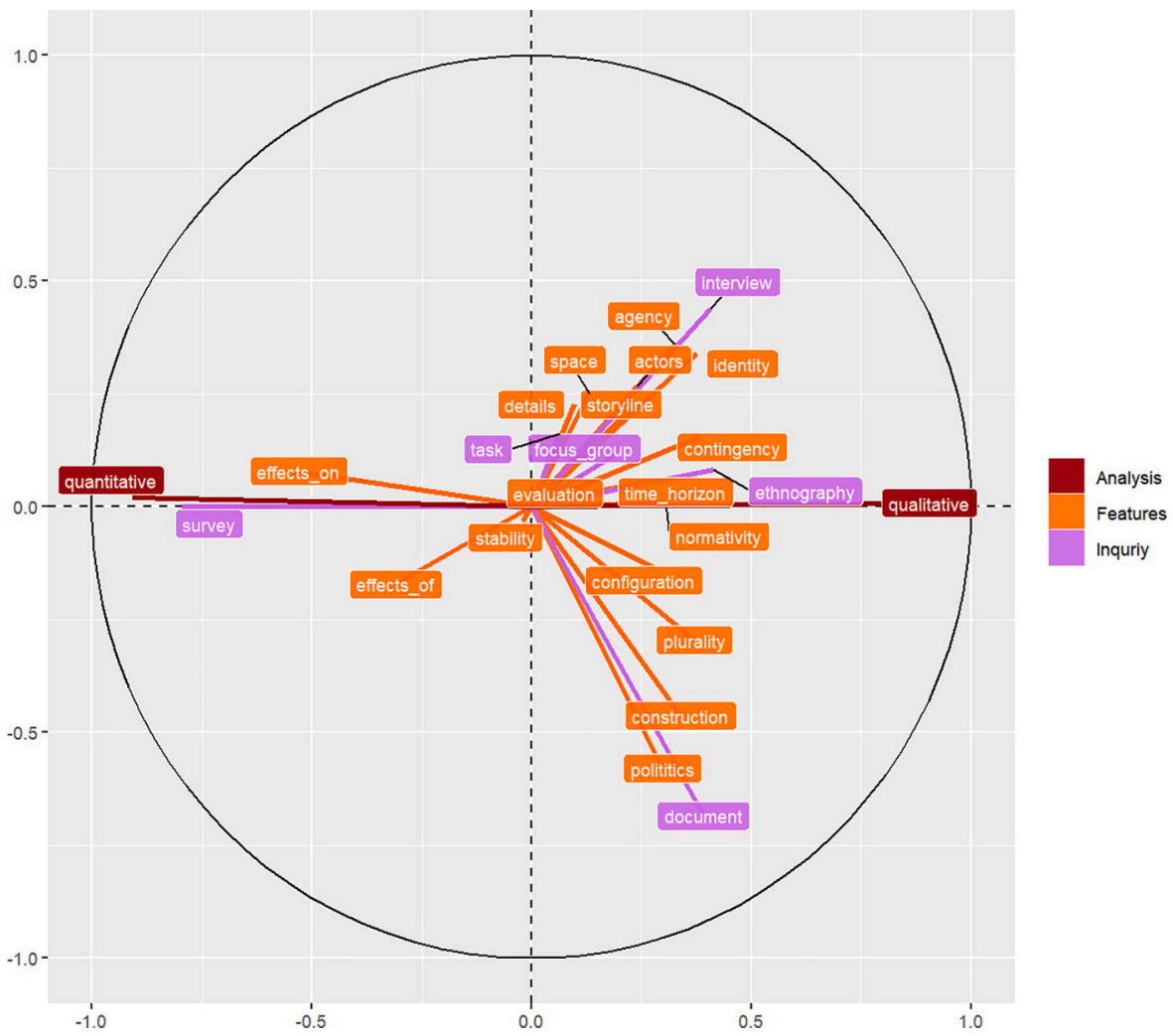

Fig. 5. Characterizing the three clusters: Contribution of active variables to the two dimensions of the PCA. 


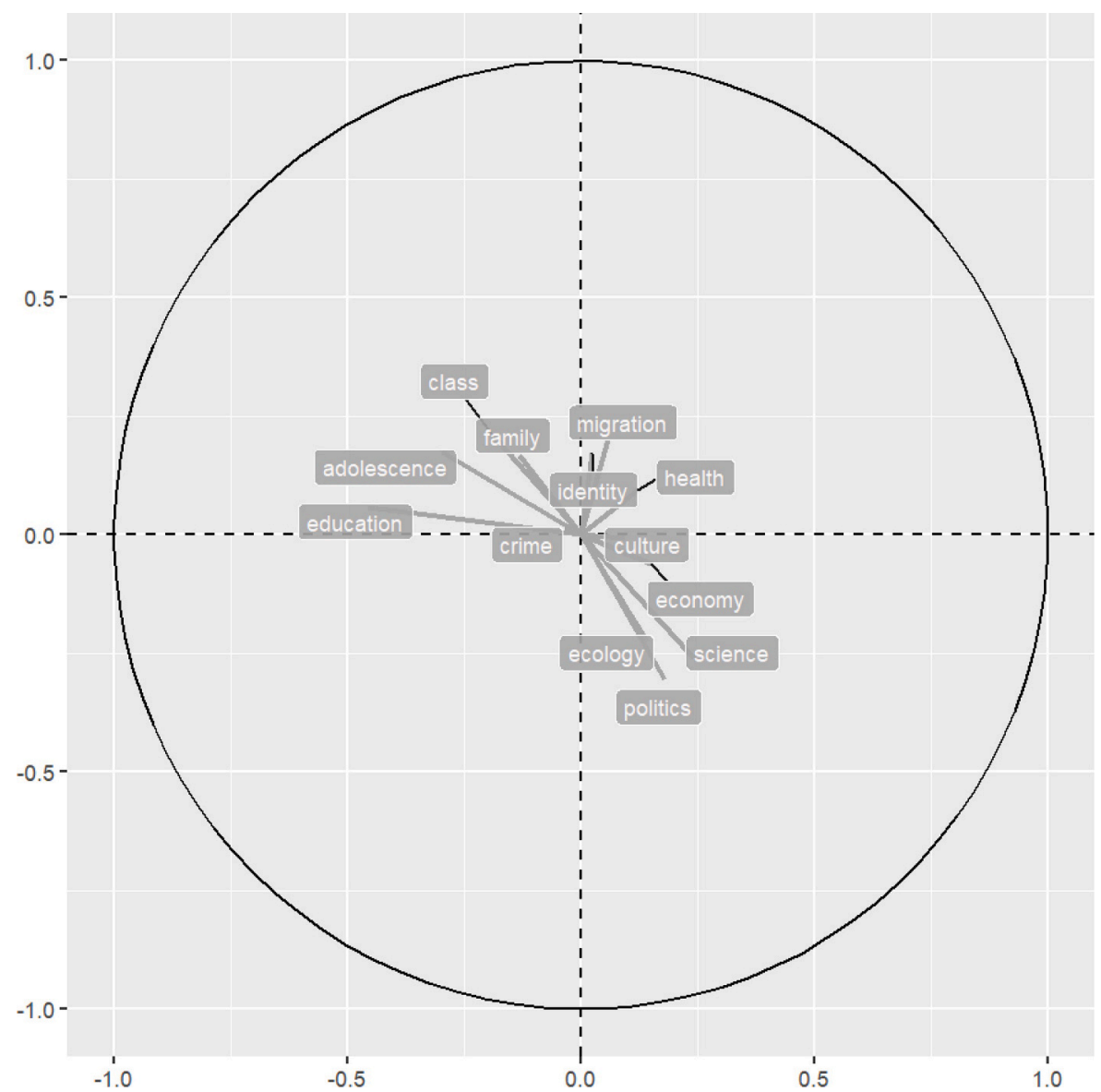

Fig. 6. Situating the three clusters within the field of sociology: areas of study as passive variable of the PCA.

and to what end the future is studied as a social fact. We therefore used the assignment of each article to a specific cluster as a starting point for an in-depth qualitative review and explored the modes in which knowledge about future orientations is produced in each cluster.

In the following three sub-sections we will characterize each cluster and spell out how respective scholars conceptualize and study the future. In each section we will highlight some articles in order to illustrate our argument and point to important lacunae.

\subsection{Studying the future as a variable: The sources and effects of aspirations}

Starting in the 1950s with the work of educational psychologists (Hills, 1955; Schultz \& Ricciuti, 1954), but soon taken over by sociologists (Kahl, 1953), the role of future aspirations and expectations became an important subject for understanding social stratification processes and social inequality.

The most influential of the studies in this cluster are associated with the Wisconsin Longitudinal Survey from which the Wisconsin model of status attainment developed (Sewell, Haller, \& Portes, 1969; cf. also beyond our sample Sewell \& Hauser, 1975; Sewell \& Shah, 1968). Research was aimed on the one hand at understanding which social factors influence educational and occupational aspirations of adolescents and young adults. On the other hand, it investigated the effects of aspirations on achievement. In the first case, future perceptions were studied as a dependent variable, in the second case as an independent variable - but in both cases the perceived future was accounted for as a quantifiable and often binary variable.

One of the overarching interests of this research is to show the connection between aspirations and class background. To explain the formation of aspirations, scholars relied strongly on the work of Archibald Haller who argues that aspirations are formed through imitation, self-reflection, and adoption. The two basic premises of this research are, first, that aspirations are positively correlated with later attainment (Domina, Conley, \& Farkas, 2011) and, second, that aspirations and expectations regarding future achievement are shaped by social context. Significant others, especially the family and peer groups, are focal in explaining aspirations, with research claiming that expectations (and subsequent achievement) depend on the expectations that others hold of a person (Duncan, Haller, \& Portes, 1968; more recently Bozick, Alexander, Entwisle, Dauber, \& Kerr, 2010). Studies within this cluster assess the (unequal) social structure of aspirations referring to socio-demographic variables. However, they rarely adopt comparative approaches that take into 
account the historic or national contexts shaping these structures.

Methodologically, research in this field is quite homogenous. It relies mostly on surveys, often longitudinal, where students or young adults are asked about their future aspirations (e.g. "Do you aspire to complete college?"). Answers are correlated with socioeconomic background, mostly race, gender, location, and immigration experiences (Haller, Otto, Meier, \& Ohlendor, 1974). This work had its heyday in the 1960s and 1970s, but is still continuing today, though with a somewhat broader focus. In the beginning the research was mostly centered on educational issues. More recent work is more strongly focused on issues of immigration, race, and gender and also broadens its scope beyond the US (Bandelj \& Lanuza, 2018; Bohon, Johnson, \& Gorman, 2006; Clark, Poulin, \& Kohler, 2009; Nurmi, 1987).

A related set of sociological studies to be found in this cluster has developed since the 1990s and focuses more on the family, adolescent deviant behavior, and future assessments in general. Researchers correlate sociodemographic characteristics with actors' aspirations about when to marry or have children (Crissey, 2005; Waller \& McLanahan, 2005) or their overall optimistic or pessimistic attitudes. In this research, one can see a slightly more complex understanding of aspirations, though the main question from educational research on social inequality remains: what explains certain aspirations and what effects do these aspirations have? The more recent literature also tends to be methodologically more open: it does not entirely rely on surveys but also includes qualitative interviews (e.g. D’Hondt, Van Praag, Van Houtte, \& Stevens, 2016; Nurmi, 1987).

\subsection{Studying images of the future: What does the future look like?}

The second cluster is more heterogeneous and shows a more complex notion of future orientations than the first cluster. Perceptions of the future are not reduced to a binary variable, but scholars explore what these perceptions precisely look like. They empirically inquire and compare the multiple gestalts of imagined futures. The focus is not on testing hypotheses or proving effects, but rather on the in-depth and often theoretically driven description of imaginaries.

These research articles reveal a profound interest in the content of images of the future as a discrete object of investigation. They assess a variety of the features detailed in Table 1: time horizons, contingency, storylines or temporal configurations of the imagined futures; agency, identities, spaces or actors associated with the future; evaluation or normativity implicit to the observed future perceptions. To provide a comprehensive picture of how the future is imagined, studies typically analyze several of these features in combination.

Research in this second cluster often studies how the future is perceived as a specific temporal sphere. Scholars take account of the time horizons (e.g. long term vs. short term futures), temporal configuration (e.g. linear vs. cyclical futures), assumptions of contingency (e.g. determined vs. open or uncertain futures) or storylines actors adopt in order to link their present situation to the imagined future. Ana Alacovska (2019), for example, draws on such features to depict the temporality inherent to quotidian hopes of Balkan creative workers and to explain what keeps these extremely precarious workers motivated.

Motivation and the perception of the future as a sphere for opportunity is another central theme in this second cluster. To what extent actors believe they can positively shape their future is essential for understanding the motivational function of expectations (Emirbayer \& Mische, 1998). Only when actors consider the future as a consequence of their own actions and not predestined by some uncontrollable force does "reasoning backwards from the future" become plausible. To this end scholars of this cluster explore how the expected future is evaluated (e.g. optimism vs. pessimism), what actor constellations are imagined as being part of the future (or not), or the level of agency actors assume they have regarding the future. For example, Margaret Frye's (2012) study finds that despite their unfavorable conditions, girls from Malawi express an extensive sense of individual agency about the future. They proudly consider themselves as "those who aspire". Optimistically believing in the openness of the future and one's agency, however unrealistic, becomes a question of morality rather than probabilistic calculation for them. Indeed, numerous studies show how having faith in the future in many contexts becomes a normative imperative and an issue of identity (Costas \& Grey, 2014; Cuzzocrea \& Mandich, 2016; Devadason, 2008; Snee \& Devine, 2018). Moreover, some studies address “waiting” (Cuzzocrea, 2019; Rotter, 2016) as a phenomenon that is inherently oriented towards the future while marked by the absence of agency.

As cluster 2 studies set out to explore the complexity of future orientations in detail, they mostly draw on qualitative methodologies. While many scholars rely on interviews and focus groups to derive future orientations directly from actors, a number of studies also include more unusual research designs. They expose participants to stimuli (like photographs, audio or video recordings) or ask them to perform tasks, e.g. producing collages of their future bodies (Coleman, 2008; Wilson \& Milne, 2016). Moreover, starting from Chinoy's (1952) study on automobile workers, scholars interested in the exact configuration of future orientations also explore them in their "natural context", i.e. by field observation or other ethnographic approaches (Boje, 1991; Halawa, 2015).

The research focusing on the way actors imagine the future demonstrates how perceptions of the future can differ in numerous ways. Many of these studies indicate that prospecting the future is increasingly a means of social distinction and highlight the importance of varying institutional setups. However, neither the precise interrelations with social structure nor the role of power are systematically explored.

\subsection{Studying the contest for the future: How is the future constructed?}

The third cluster consists of studies interested in the contested processes of construction and diffusion of future expectations. Of the three clusters we distinguish, it is the smallest and most recent cluster, having emerged only after the turn of the century.

Articles in this cluster are concerned with the process in which perceptions of the future are "made" and the social struggles in which particular visions become dominant. These studies look in detail at how, by whom, and based on what resources the future is crafted. For example, David Gibson's (2011) research on the Cuban missile crisis skillfully reconstructs how President Kennedy's 
decision for a blockade resulted from conjoined efforts of narrating the future. Using historic audio recordings Gibson shows that the Executive Committee of the National Security Council started from several future scenarios. During the deliberations, particular stories and the respective future consequences were progressively suppressed, promoting a shift in preferences from an immediate air strike towards a blockade intended as a warning to Khrushchev.

Like Gibson, most scholars of this third cluster consider expectations to emerge in discursive processes. They focus on understanding the stories, conversations, metaphors, public and expert controversies in which future states of the world are expressed. However, a considerable number of studies expand this discursive perspective and also address the manifold devices, technologies and objects used to create and consolidate perceptions of the future. This broadened research focus is most characteristic of the sociology of expectations - a research strand that many scholars of this third cluster are associated with or actively refer to (e.g. Nerlich \& Halliday, 2007; Yearley, 2009). The sociology of expectations emerged around authors such as Harro van Lente and Nik Brown (Borup, Brown, Konrad, \& Van Lente, 2006; Brown \& Michael, 2003; Van Lente, 2012) and is closely related to the more encompassing science and technology studies (STS). Scholars within this domain study the role of expectations in the natural sciences and technological innovation processes but are also increasingly concerned with knowledge production in economics and business studies.

Often, the investigation of the discursive construction processes reveals multiple and co-existing ideas about how the future will unfold. The plurality of future expectations is therefore a second major feature authors of this third cluster are interested in. Scholars are interested in divergent future expectations within one particular situation or organization not in order to depict their gestalt, but to explore how different perceptions of the future interact, conflict or are layered. In order to stress the cultural embeddedness of construction processes, some studies draw on comparative research designs which juxtapose imagined futures of different countries or different historical moments (Hulme, 2008; Jasanoff \& Kim, 2009).

A major theme of the studies addressed within this cluster is their concern with power. Authors (sometimes implicitly) build on the assumption that command over the expected future is a powerful and therefore contested resource (see also the classic work of Koselleck, 1979). It is particularly due to their performative effect, i.e. their potential to trigger self-fulfilling prophecies that expectations are considered important instruments of domination within markets, democratic movements or technological innovation processes.

What we label the politics of expectations is therefore a third feature addressed in this cluster. Here, researchers are explicitly interested how particular perceptions become "hegemonic" (Laclau \& Mouffe, 2001) and are thus imposed on social groups or society as a whole - while other perceptions are consigned to oblivion. Many of these articles look at how actor groups argue for divergent visions of the future that meet their present or future interests (e.g. Andersson \& Keizer, 2014; Kolarskabobinska, 1994). Studies of this cluster explore social domains in which actors struggle about the "right" future. They are often anchored in political sociology and address e.g. political campaigns or environmental and social movements (Anderson, 2017; Nyberg, Wright, \& Kirk, 2018); they explore - often from an STS perspective - how future developments are contested within academia and R\&D labs (Bakker, Van Lente, \& Meeus, 2011); or they emanate from economic sociology and study how the politics of expectations shapes economic forecasting, financial markets and business models (Abolafia, 2010; Fastenrath, Orban, \& Trampusch, 2018; Holmes, 2009).

Almost all articles subsumed into this third cluster use qualitative modes of inquiry and analysis. Some studies attempt to understand the mechanisms and dynamics of the construction and diffusion of futures firsthand, on the ground, by employing ethnographic methods. However, most researchers within this cluster reconstruct the processes they are interested in by analyzing the relicts of these processes, thus taking a historical approach. Verbatim transcripts, audio recordings, reports, and other archival material are used to study how the future was constructed within a particular context. Additionally, the process of diffusion is reconstructed by means of media or press analysis.

Though power and symbolic struggles are important to most studies within this third cluster, they never adopt a structuralist perspective. While they excessively focus on rhetoric and technologies that allow actors to impose visions of the future in particular situations, processes or institutions, they omit structural inequalities both as causes and consequences of dominating the contested construction of the future.

\section{Diversification II: The emergence of the three research clusters}

Each of the three clusters approaches future orientations from a different perspective. They employ different methods to capture and analyze perceptions of the future and show interest in different features related to the future. Fig. 7 captures these three clusters over time. It depicts how the articles published in each decade spread over the plane. The analysis reveals that the clusters have emerged at different points in time and developed in relative isolation from each other. ${ }^{14}$

Our graphs show a rather homogenous field of research up to the 1980s, which is focused on cluster 1 studies. Starting in the 1990 s, the picture changes: overall interest in future orientations increases significantly but the methodological approaches employed to assess the future and the substantial topics investigated also diversify. As the graphs indicate, the second upswing is partly driven by revived scholarly activity in cluster 1, but primarily by the emergence of cluster 2 in the 1990s and cluster 3 in the 2000 s. The second upswing thus contains a diversification of the research field, with the adoption of new approaches of how to study future orientations. This epistemological diversification widely corresponds with the expansion of sociological subfields interested in studying perceptions of the future which we have depicted in Section 4.

\footnotetext{
$\overline{14}$ A complementary citation-based network analysis confirms this picture: the three clusters are discernable, and cluster 1 particularly stands apart as a closed network.
} 

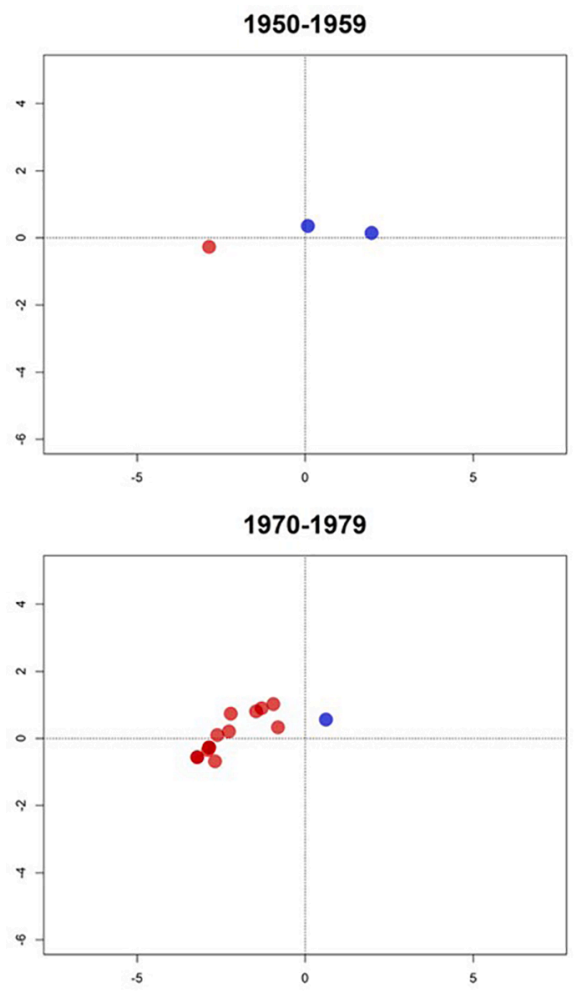

1990-1999

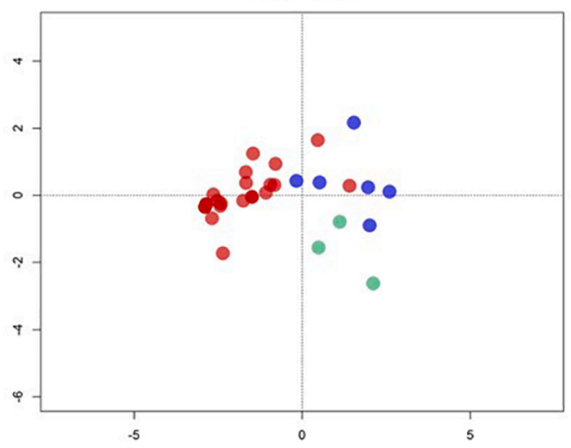

2010-2019

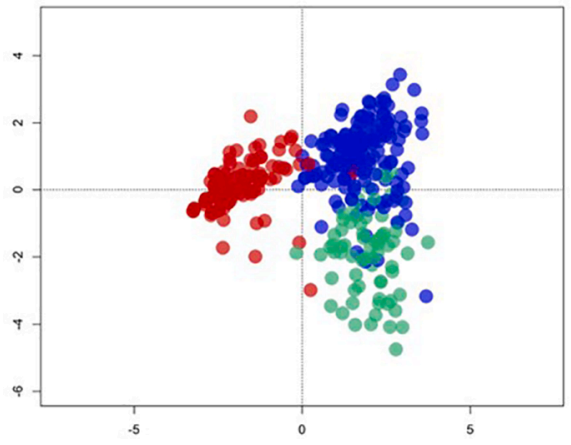

1960-1969

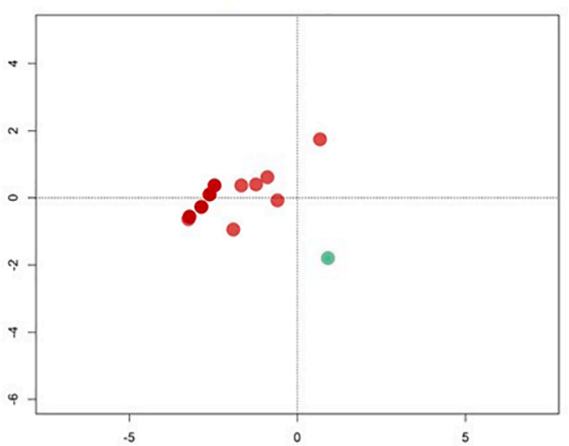

1980-1989

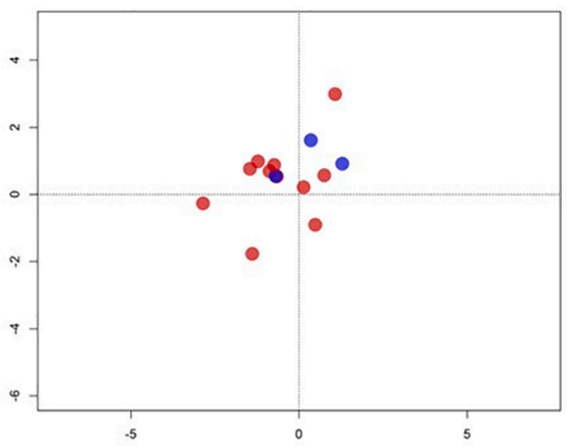

2000-2009

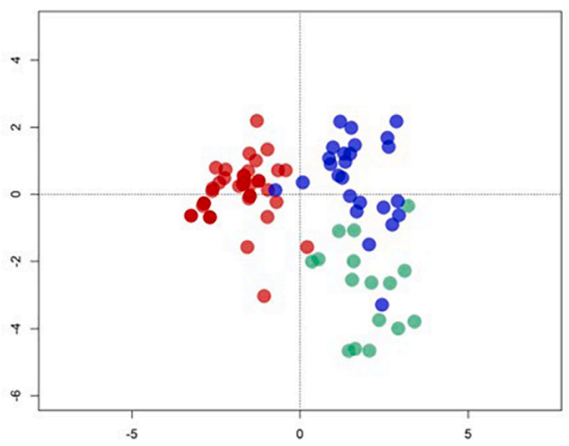

Fig. 7. Distribution of articles per cluster and decade. 
What have been the drivers behind this diversification of the research field? Combining Figs. 6 and 7 indicates that the emergence and growth of each cluster can be related to broader dynamics within the field of sociology and society at large. Though theoretical developments and changing empirical relevance of disciplinary subfields do not offer strict causal explanations, they allow considering the respective historical contexts relevant for the evolution of research fields.

Cluster 1 studies are primarily associated with the sociology of education and the family. The emergence of this cluster and the first upswing of our research field coincide with the first heyday of the sociology of education in the 1960s and 1970s. Educational aspirations and their anchoring in the family were considered as both explanation and antidote to social stratification and inequality. With skepticism towards modernization theories and the engineering of progress through educational reform rising in the 1980s, such an optimistic approach was profoundly challenged (cf also Section 4). The revival of interest in the sociology of education and the sociology of family, manifested in large international research programs in the early 2000s, was then driven by different theoretical approaches. Scholars now considered educational outcome as determined by inequality and missing opportunity structures. Educational aspirations were primarily considered a covariate (Domina et al., 2011; Maralani, 2014). Moreover, advances in quantitative methods within sociology have allowed studying these dependencies of aspirations as dynamic mechanisms.

The emergence of the second cluster, i.e. studies that investigate the multifaceted ways in which actors imagine the future, coincides with a time in the 1990s when capitalist dynamics, large scale societal transformations, globalization, and perceived contingency of social development increased almost everywhere. Indeed, the sociological subfields that contributed to the growth of cluster 2 explicitly focus on moments of crisis, breaches, and change (like the sociologies of migration, health, and crime); or have increasingly considered their object of investigation as contingent (like gender and identity studies). The expansion of interest in future orientations coincides with enlarged sociological interest in moments of indeterminacy and transitions which was triggered by accelerated societal transformations. It is in instances where the future is no longer perceived to be a mere prolongation of the present that the multiple ways in which actors imagine the future gain attention. The popularity and systematization of qualitative research methods occurring with the post-positivist turn in the 1980s and the advancements in observational methods in the 1990s provided sociologists with the tools to study and understand the multiplicity of future orientations in more detail. Moreover, taking account of this multiplicity from a temporal perspective was facilitated by theoretical advances in the sociology of time (e.g. Abbott, 2001; Bergmann, 1992; Hassard, 1990). Elucidating how actors perceive and construct time has led to theoretical frameworks which help to explore and describe the gestalt of future orientations in more detail and thus to conduct the research prevalent in cluster 2.

Research in cluster 3, which emerged at the turn of the century, explores much more strongly how power interferes in the construction, diffusion and contestation of imagined futures. This research interest is in line with the much broader sociological concern for the construction of narratives, meaning, frames, discourses and the related hegemonic or symbolic struggles (Bourdieu, 1991; Laclau \& Mouffe, 2001). While this "cultural turn" had occurred in social theory by the mid-1980s (Nash, 2001; Swidler, 1986), important subfields such as economic sociology and political sociology have integrated this perspective only more recently. Informed by culturalist and often constructivist approaches and geared with text-based methods such as discourse-, frame- or conversation analysis, sociologists discovered perceptions of the future as a target for economic and political contestation. In the field of economic sociology, some scholars have consequently even developed theoretical frameworks that promote future orientations as the driving force of capitalism (Beckert, 2016; Esposito, 2013; Snyder, 2016; cf. Urry, 2016). Moreover, the emergence of this third cluster can be related to the increasing role of science and technology studies within sociology. Emanating from this research field, scholars started to investigate how the contested construction of future expectations is central to understanding technological innovations (Borup et al., 2006; Brown \& Michael, 2003). Finally, during the last decade, research in this third cluster has also been inspired by the political contestation surrounding recent financial and ecological crises. Both the sociology of finance and environmental sociology have realized the political nature of perceptions of the future and the technologies used for calculating probable futures and made the future an object of their investigations.

The analysis across time reveals that the three clusters we distinguish do not only employ different approaches of how to empirically study the future. They have emerged at different points in time and can be related to different developments within sociology and society at large. They represent three different sociological traditions of studying the future as a social fact. As we will see in the next section, they also take place in different arenas of academic deliberation.

\section{What journals? Important outlets of the research field}

The composition of our corpus shows that there are various outlets for sociological research concerned with perceptions of the future. The articles we collected originate from 154 different journals. Fig. 8 displays all journals in which at least four articles of our sample were published. These 32 journals represent the major academic outlets in which the sociological study of the future takes place.

To depict how the three clusters relate to particular outlets we have used journal information as a passive categorical variable of the PCA. Thus, the various journals can be projected in the space defined by the articles and their inherent epistemological structure (see Fig. 8, small graph). Zooming into this representation, we can explore the location of specific journals and how they relate to the three clusters of articles (confer larger graph). In Fig. 8 the icon size indicates the number of articles from our sample published in each journal. The different colors refer to the rank of the journal, relying again on the WOS JCR Ranking for Sociology in 2017, according to normalized Eigenfactor (cf. appendix). We distinguished between the top 10, top 20 and top 40 sociological journals within this ranking, other sociology journals (according to WOS) and journals that were not included in the WOS sociology category, like Organization Studies and Time \& Society (cf. Section 3 and appendix).

On the left side of the plane the graph indicates a multiplicity of journals that mostly correspond to cluster 1 - the largest cluster 


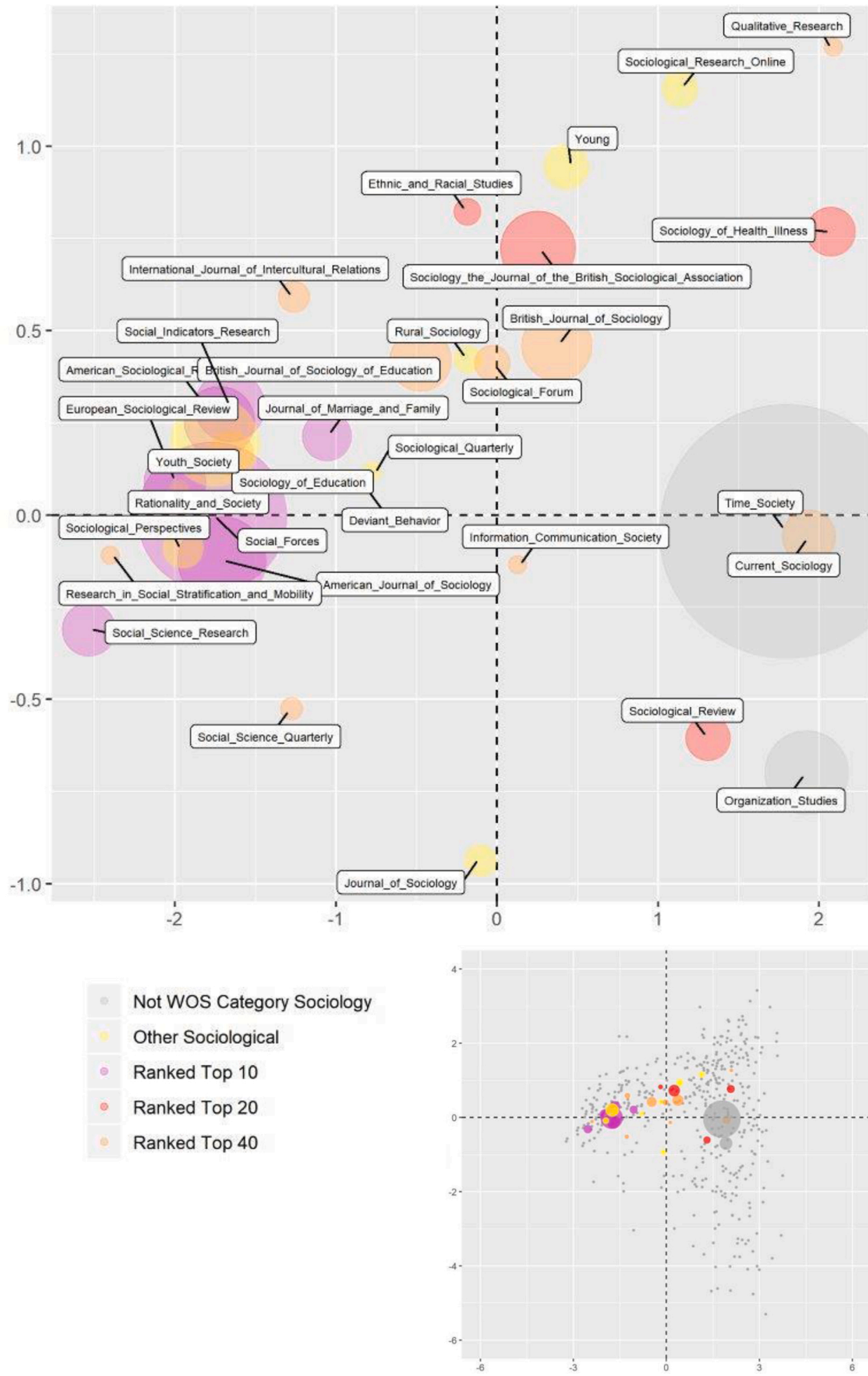

Fig. 8. Where are future orientations studied? Journals as passive qualitative variable of the PCA, icon size representing the number of future related articles published per journal. 
across time. Social Forces, the American Journal of Sociology and Youth \& Society are major outlets of scholarship connected with this cluster. Among the associated journals one finds specialized sociology journals that are dedicated to the particular objects of investigation of this cluster: education (British Journal of Education, Sociology of Education), adolescence (Youth \& Society), family (Journal of Marriage and Family) and inequality (Research in Social Stratification and Mobility). Others are focused on quantitative methods which are predominant in this cluster (Social Science Research, Social Indicators Research). But we also find most of the general, (mostly American) flagship journals of sociology within this cluster: the American Journal of Sociology, the American Sociological Review, the European Sociological Review, Social Forces, or Social Science Research. Moreover, all top 10 ranked journals in our sample are exclusively located in the vicinity of cluster 1.

Located in the upper right, the journals corresponding to cluster 2 differ from this characterization. Two major outlets, Sociology The Journal of the British Sociological Association and the British Journal of Sociology, are, as indicated by their names, predominantly British journals. Moreover, we find several other well-known journals, many of them located somewhere between the top 20 and top 40 on the JCR Ranking. Some of these journals are dedicated to the specific objects of investigation of this cluster, like health (Sociology of Health and Illness) or identity and migration (Ethnic and Racial Studies); but we also find Qualitative Research which focuses on the methods applied in this cluster. Moreover, cluster 2 shares two major outlets with cluster 3: Time \& Society, an interdisciplinary journal dedicated to the interplay of time and social phenomena; and Current Sociology, the journal of the International Sociological Association.

Looking at the lower right of the plane, we see that apart from the two aforementioned outlets, cluster 3 corresponds to very few journals which publish empirical work on future perceptions in larger numbers. Sociological Review constitutes the only top 20 ranked journal which serves as an outlet for this cluster, while another major outlet, Organization Studies, like Time \& Society, is qualified as a rather interdisciplinary journal. Indeed, much of the research comprised in this cluster is published in a variety of journals open to culturalist and constructivist sociological approaches, but in which future orientations have only played a subordinate role until now.

This comparison shows that each of the three clusters is related to distinctive arenas of academic deliberation. In line with their differing research interests and methodological approaches, the research speaks to journals dedicated to different objects of investigation and methods. More surprisingly, they also differ in their national origin and sociological reputation. It is striking that most major American journals are situated on the left, in vicinity to cluster 1, whereas we find various British (Sociological Review, Sociology, the British Journal of Sociology, Social Research Online) and internationally oriented journals (Current Sociology, Young) associated with cluster 2 and 3.

Though not showing strong effects, an analysis of the national origin of authors' affiliation pointed to the same national differentiation: research in cluster 1 is mainly US scholarship, whereas cluster 2 and 3 are driven by British and "international" research. Perhaps an effect of the congruence of researchers and journals in terms of nationality, research in cluster 1 has mostly found its way into American journals, which happen to be also the most prestigious sociological journals, while cluster 2 research is concentrated in very respected but not top ranked journals that often have their location in European countries. Finally, it appears as if cluster 3, the youngest of our three research clusters, has so far developed only a few clearly identified journals that serve as their arenas of academic deliberation. The outlets in which sociologists more frequently discuss the contested construction of the future (cluster 3) are not exclusively sociological journals but speak to a larger, interdisciplinary audience.

\section{Conclusion and future research paths}

Though sociology as a discipline mostly orients itself toward the past and the present, our analysis has highlighted a small but expanding sociological literature that empirically studies perceptions of the future. Emanating from a sociology of knowledge perspective, we have systematically cartographed this field of research: we have explored its epistemological structure, its historical development, and its internal divisions.

Drawing on a qualitatively driven mixed methods analysis of 571 journal articles, we have particularly identified three distinct research clusters within this field: The first considers aspirations as a quantifiable variable and investigates causal dependencies explaining the distribution and social consequences of aspirations. The second is interested in the gestalt of future perceptions and analyzes the multifaceted ways in which actors imagine the future. The third cluster is concerned with the contested construction and diffusion of future expectations and the role of power in these processes. Following the development of these three clusters over time, we find that interest in the future as a social fact has not only increased but also diversified. While early contributions in the 1960s were limited to cluster 1 studies and mainly inquired educational aspirations, the emergence of the second and third cluster since the 1990s is marked by new epistemological perspectives and connects to a much broader set of sociological themes - from migration to financial markets. This shift in research reflects the increasing relevance of more constructivist, interpretative, and culturalist approaches in sociology and probably also that future orientations of actors are especially amenable to qualitative research approaches.

One striking finding of our analysis is the relative isolation of the three sociological research clusters interested in perceptions of the future. They have emerged at different points in time, relate to different sociological traditions and appear in different journal outlets. The relative neglect of substantial subjects, epistemological perspectives or methodologies prevailing in the other clusters seems, however, not so much to be justified in terms of substance. Rather, this mutual ignorance indicates a number of lacunae that could be overcome by more awareness of the field as a whole. Entangling the versatile approaches could open up new promising research paths. Building on the detailed analysis of each cluster we therefore want to emphasize four exemplary domains that illustrate the potential of more integrative perspectives and thus merit further scholarly attention.

First, apart from cluster 2, research interested in the future as a social fact hardly takes advantage of frameworks provided by the sociology of time. A more nuanced understanding of expectations and their inherent temporality might, however, also prove beneficial 
beyond this cluster. Scholars interested in the contested construction of the future (cluster 3) can particularly learn from social memory studies, which has long investigated how stories of the past are used to dominate the present (de Saint-Laurent, Brescó de Luna, Awad, \& Wagoner, 2017; Tilly, 1994). Researchers might explore how the observed "politics of expectations" are linked to specific perceptions of time - like the ideas of progress or nostalgia, long-term or short-term future - or how narrating the future often involves re-interpreting the past and present (Simko, 2018). Moreover, scholars interested in the causes and consequences of aspirations may gain by considering aspirations as multidimensional variables and integrating e.g. the contingency or temporal configuration of imagined futures into their models. In this context the quantitative-qualitative divide between the clusters is also striking. So far, very little use has been made of either mixed methods approaches or novel computational methods such as text mining. Both might enable researchers to account in detail for more complex and nuanced future perceptions while at the same time systematically linking this inquiry to a quantitative analysis of social structure and power.

Second, the research field warrants a more comprehensive understanding of power, inequality and interpretative struggles related to perceptions of the future. What we called the politics of expectations is so far almost exclusively an issue within cluster 3 . This research, however, often takes an interactionist micro-perspective with little mentioning of the role of social class, social inequality and social structure - all prominent topics in cluster 1 . The focus could be stronger on the inequalities in shaping future perceptions and their structural preconditions. Who is able to enforce their vision and what classes, ethnicities or genders do have less of a say in the matters of the future? Vice versa, research could put more attention to the discursive construction of the future as a strategy of domination. Why are some futures generally considered too big to fail while others are negligible to societies? And how is actors' actual and perceived agency affected by these imagined futures? While many studies acknowledge that controlling perceptions of the future is crucial for dominating the present, a more comprehensive analysis of the interrelation between power and expectations would be a much-warranted addition.

Thirdly, it is mostly research in clusters 1 and 2 that relates future expectations to institutional factors. This, however, is hardly ever done in a truly comparative or historical perspective, approaches that one finds merely in cluster 3. To investigate variance in expectations based on a comparison of different institutional setups would clearly generate highly interesting research findings. How are broad societal institutions such as national welfare states, patriarchy, political systems, and capitalism affecting future expectations prevalent in particular social settings? How are the velocity, tone, and persuasiveness of projected futures dependent on cultural frames (Cerulo, 2006)? The institutional and cultural embededdness of future orientations can probably be best examined from a comparative perspective. Studies that account for national "varieties of future expectations" may enable the detection of large-scale causes and consequences of specific imagined futures. Equally relevant would be the historical perspective. The lack of diachronic comparisons through the systematic scrutiny of past futures represents a research gap in the field we investigated. While historians increasingly explore "the history of the future" (Hölscher, 2016; Levy, 2017; Radkau, 2017), most sociologists focus on contemporary future expectations. A "historical sociology of the future" offers multiple paths of promising research. Its main potential is to reconstruct how images of the future depend on specific historical contexts. We need to understand better how different historical epochs, acceleration, progress, and crises are linked to specific notions of the future (Beckert, 2017). Moreover, a historical perspective is well suited to account for "failed" futures, i.e. the role of wrong predictions, disappointed expectations, and forgotten utopias and the ways societies react to these unfulfilled future expectations - a topic that offers insights into how perceptions of the future affect the social world but finds little attention in either of the three clusters.

A further topic, which we consider to hold particular potential for a more integrated perspective is the nexus of (digital) technology and imagined futures. Technology, either as an instrument to depict and pursue desired futures or as something that develops from expectations, is only a topic of research in cluster 3 . However, it is also highly relevant to research interests associated with the other two clusters. While modern institutions such as markets, democracy, and scientific research rely on the notion of an open and contingent future, in much of the recent public discourse on algorithms, the future appears as (at least probabilistically) foreknowable or determined. Sociological analysis could address whether digital technologies affect the way actors perceive the future (cluster 2). How do new modes of algorithmic and technocratic governance as well as the ever increasing imperative to predict hamper our imaginary capacities? Technology could also become an important issue in stratification research (cluster 1). Social scientists can critically scrutinize the narrative of "neutral" algorithmic predictions and demonstrate how social prejudice and power are built into algorithmic models (O'Neil, 2017). How does the spread of (digital) technologies influence the opportunities of different social groups to imagine future social outcomes? And do actors' aspirations still make a difference in a world governed by algorithmic prediction? The impact of digital technologies on imagined futures is relevant for economic, political, and environmental subjects already predominant in cluster 3, like the use of algorithmic trading in financial markets or the climate models in environmental studies. However, algorithmic forecasts are also increasingly important for, e.g., educational opportunities, partner selection, medical treatment or verdicts, i.e. domains that have been more associated with the other clusters.

As these research paths emphasize, focusing on future perceptions encourages innovative research perspectives within and beyond established sociological paradigms. Images of the future orient individual and collective behavior and are thus relevant for the explanation of social outcomes (see already Bell \& Mau, 1973). To consider the future more systematically as a social fact allows for new insights into many of the phenomena investigated by sociologists. The study of the emergence, diversification and structure of this research field shows that scholars increasingly see the research opportunities and possibilities for enlarging sociological knowledge by studying imagined futures - as they are reflected in actor expectations, aspirations, and future beliefs. It is a trajectory that hopefully has a bright future. 


\section{Appendix}

In this appendix we describe in detail our search strategy for assembling the set of 571 research articles which form the basis of our qualitatively driven mixed methods analyses. Each selected article had to meet the five criteria (a-e) outlined in Section 3.

First, and most importantly, we searched the Web of Science (WOS) database for appropriate English language research articles. We searched for the terms "future", "aspiration" or "expectation" to occur at least once in title, abstract or keywords of respective articles (referred to as "topic" by WOS). ${ }^{15}$ Applied to the WOS category "sociology" for the years 1950 to 2019 this search produced almost 8500 results. By reading the titles and where necessary abstracts and further sections, for each result we decided whether criteria (d) and (e) were met. This search generated 431 relevant articles, i.e. $75 \%$ of our overall sample. Despite this large result, we were not wholly convinced these articles would capture the field comprehensively. To compensate for some of the selection bias inherent to WOS and in line with our qualitatively driven approach, we therefore complemented this search with three further search strategies.

While WOS provides good coverage for recent years (though with a certain lag for the most recent two or three years, see footnote 5), it is less comprehensive for the pre-digitalized era. We wanted to ensure that we captured at least all of the relevant articles in leading general sociology journals. Our second search strategy therefore considered the top 40 journals of WOS JCR Ranking for Sociology in 2017, ranked according to normalized Eigenfactor. We then chose those journals that according to their self-description classify as "general", i.e. are not restricted to a specific strand of sociology (like Socio-Economic Review or Sociology of Education) nor to a specific methodology (like Qualitative Research or Social Networks). We thus searched all published issues of the American Journal of Sociology, the American Sociological Review, the British Journal of Sociology, Current Sociology, the European Sociological Review, Social Forces, Social Problems, Social Science Quarterly, Social Science Research, Sociological Forum, Sociological Review, Sociology - the Journal of the British Sociological Association (in alphabetical order), for relevant articles in the respective journals' archive. This search generated additional 11 articles which met our criteria but were not included in WOS.

The WOS category for sociology included 147 journals for the year 2017, presenting a diverse set of journals that are associated with sociology. The criteria for this selection are not entirely transparent and, as always, the boundaries of such selections can be contested (Leydesdorff \& Bornmann, 2016). In particular we found that two major journals in which we knew sociological research on future orientations appeared were not included in the WOS category: Time \& Society and Organization Studies. Aware of the interdisciplinarity of these two journals but also their relevance for the field we were trying to study, we first searched both archives for articles that met our criteria (b) to (e). In a second step, for each article we then determined whether it really qualified as sociological, according to a fixed set of criteria (see footnote 4). This mode of search identified a further 78 sociological articles that empirically study future orientations.

Finally, in order to make sure we had not missed further major arenas of the research field, and to partly compensate for WOS emphasize on American journals, we conducted what may be termed a "traditional" literature search. We closely scrutinized the reference lists of articles (e.g. Borup et al., 2006; Coleman \& Tutton, 2016; Mische, 2009; Mische, 2014; Tavory \& Eliasoph, 2013) and books (e.g. Appadurai, 2013; Beckert, 2016; Daipha, 2015; Urry, 2016) that provided overview sections which then led us to further publications which met our criteria. Moreover, we consulted various colleagues working on related issues for further references. While this traditional search yielded 51 additional articles, it did not indicate new arenas or subfields, which had not yet been covered.

Though the combination of these four search strategies has yielded a large, comprehensive sample, our text corpus has three major limitations: First, by relying only on English language articles our study captures the "international field" of sociology, but neglects that relevant research studying future orientations may also be conducted in more nationalized areas of sociology where other native languages are still predominant. Though the authors' affiliations of the corpus are located in 36 different countries, we see a clear overrepresentation of authors from the US or the UK ( $42 \%$ and $23 \%$ of all articles). ${ }^{16}$

Second, our search strategies started from the explicit mention of future, aspiration or expectation in potential texts. We assume that most scholarship that empirically studies future orientations will at some point mention one of these terms. Nevertheless, we might have missed sociological work that in some respect relates to future orientations but does so much less explicitly. This may be the case for the research strand emerging around Ulrich Beck's assessment of "risk society", which indeed pointed to an altered perception of the future but without explicitly mentioning it.

Third, the decision to only focus on research articles and disregard scholarly monographs obviously limits our account of the research field. Important books, like for example Ely Chinoy's (1955) seminal analysis of the aspirations of American automotive workers or Pierre Bourdieu's (1979, French original in 1963) ethnographic study of the transformation of time horizons in Algeria during the 1950, are not included. We did not opt for this research choice out of disrespect for the book genre, but primarily out of methodological considerations. While reading, understanding and coding 571 articles is an extensive but feasible endeavor, finding all relevant books, as well as reading, understanding and coding them would have been unmanageable. The inclusion of books would have rendered any coherent coding and even more so any quantified approach of analysis impossible. Aware of this limitation, we are confident that our text corpus still provides a suitable overview of the research field, as book publications are more often than not accompanied or preceded by respective journal articles, which we cover in our sample (Chinoy, 1952).

\footnotetext{
${ }^{15}$ For search strategies beyond WOS we used the search engines provided by respective journals and adopted the same basic search syntax to filter potentially interesting articles as described above. If search engines did not allow to search titles, articles, and keywords, or if no search engines were available, we searched entire documents for occurrence of the three terms.

${ }^{16}$ Articles with at least one author from the US or the UK.
} 


\section{Acknowledgements}

\section{Our paper gained substantially from the insightful comments of Michèle Lamont, Akos Rona-Tas, Marcin Serafin, our colleagues at the MPIfG and three anonymous reviewers. We thank Tim Fenkner and Martin Widdig for their assistance with establishing the dataset and coding the articles and are grateful for the support received by the MPIfG library, particularly Cora Molloy.}

\section{References}

Abbott, A. (2001). Time matters: On theory and method. Chicago: University of Chicago Press.

Abbott, A. (2005). The idea of outcome in US sociology. The politics of method in the human sciences, 393-426.

Abolafia, M. Y. (2010). Narrative construction as sensemaking: How a Central Bank thinks. Organization Studies, 31(3), 349-367.

Adam, B. (2013). Timewatch: The social analysis of time. Malden: John Wiley \& Sons.

Adam, B., \& Groves, C. (2007). Future matters: Action, knowledge, ethics. Leiden: Brill.

Alacovska, A. (2019). 'Keep hoping, keep going': Towards a hopeful sociology of creative work. The Sociological Review, 67(5), 1118-1136.

Anderson, B. (2017). Emergency futures: Exception, urgency, interval, hope. The Sociological Review, 65(3), 463-477.

Andersson, J. (2018). The future of the world: Futurology, futurists, and the struggle for the postcold war imagination. Oxford, New York: Oxford University Press.

Andersson, J., \& Keizer, A. G. (2014). Governing the future: Science, policy and public participation in the construction of the long term in the Netherlands and Sweden. History and Technology, 30(1-2), 104-122.

Appadurai, A. (2013). The future as cultural fact. London: Verso.

Bakker, S., Van Lente, H., \& Meeus, M. (2011). Arenas of expectations for hydrogen technologies. Technological Forecasting and Social Change, 78(1), 152-162.

Baldwin, K. (2017). "I suppose I think to myself, that's the best way to be a mother": how ideologies of parenthood shape women's use for social egg freezing technology. Sociological Research Online, 22(2), 15. https://doi.org/10.5153/sro.4187.

Bandelj, N., \& Lanuza, Y. R. (2018). Economic expectations of young adults. Socius, 4. https://doi.org/10.1177/2378023118795953.

Beckert, J. (2016). Imagined futures: Fictional expectations and capitalist dynamics. Cambridge: Harvard University Press.

Beckert, J. (2017). Die Historizität fiktionaler Erwartungen. MPIfG Discussion Paper.

Bell, D. (1973). The coming of post-industrial society: A venture in social forecasting. New York: Basic Books.

Bell, W., \& Mau, J. A. (1973). The sociology of the future: Theory, cases, and annotated bibliography. New York: Sage.

Berger, P. L., \& Luckmann, T. (1991). The social construction of reality: A treatise in the sociology of knowledge. Penguin Books.

Bergmann, W. (1992). The problem of time in sociology: An overview of the literature on the state of theory and research on the Sociology of Time, 1900-82. Time \& Society, 1(1), 81-134.

Bohon, S. A., Johnson, M. K., \& Gorman, B. K. (2006). College aspirations and expectations among Latino adolescents in the United States. Social Problems, 53(2), $207-225$.

Boje, D. M. (1991). The storytelling organization: A study of story performance in an office supply firm. Administrative Science Quarterly, 36(1), 106-126.

Borup, M., Brown, N., Konrad, K., \& Van Lente, H. (2006). The sociology of expectations in science and technology. Technology Analysis \& Strategic Management, 18 (3-4), 285-298.

Bourdieu, P. (1979). Algeria 1960: The disenchantment of the world. Cambridge: Cambridge University Press.

Bourdieu, P. (1991). Language and symbolic power. Cambridge: Harvard University Press.

Boyle, P., \& Haggerty, K. D. (2012). Planning for the worst: Risk, uncertainty and the Olympic Games. British Journal of Sociology, 63(2), 241-259.

Bozick, R., Alexander, K., Entwisle, D., Dauber, S., \& Kerr, K. (2010). Framing the future: Revisiting the place of educational expectations in status attainment. Social Forces, 88(5), 2027-2052.

Brannen, J., \& Nilsen, A. (2002). Young people's time perspectives: From youth to adulthood. Sociology - the Journal of the British Sociological Association, 36(3), 513-537.

Brown, N., \& Michael, M. (2003). A sociology of expectations: Retrospecting prospects and prospecting retrospects. Technology Analysis \& Strategic Management, 15(1), $3-18$.

Cerulo, K. A. (2006). Never saw it coming: Cultural challenges to envisioning the worst. Chicago: University of Chicago Press.

Chinoy, E. (1952). The tradition of opportunity and the aspirations of automobile workers. American Journal of Sociology, 57(5), 453-459.

Chinoy, E. (1955). Automobile workers and the American dream. Garden City: Doubleday.

Clark, S., Poulin, M., \& Kohler, H. P. (2009). Marital aspirations, sexual behaviors, and HIV/AIDS in rural Malawi. Journal of Marriage and Family, 71(2), 396-416. Coleman, R. (2008). ‘Things that stay': Feminist theory, duration and the future. Time \& Society, 17(1), $85-102$.

Coleman, R., \& Tutton, R. (2016). Introduction to futures in question: Theories, methods. The Sociological Review, 65(3), 440-447.

Costas, J., \& Grey, C. (2014). The temporality of power and the power of temporality: Imaginary future selves in professional service firms. Organization Studies, 35(6), 909-937.

Crissey, S. R. (2005). Race/ethnic differences in the marital expectations of adolescents: The role of romantic relationships. Journal of Marriage and Family, 67(3), $697-709$.

Cuzzocrea, V. (2018). "Rooted mobilities" in young people's narratives of the future: A peripheral case. Current Sociology, 66(7), 1106-1123.

Cuzzocrea, V. (2019). Moratorium or waithood? Forms of time-taking and the changing shape of youth. Time \& Society, 28(2), 567-586.

Cuzzocrea, V., \& Mandich, G. (2016). Students' narratives of the future: Imagined mobilities as forms of youth agency. Journal of Youth Studies, 19 (4), 552-567.

Daipha, P. (2015). Masters of uncertainty: Weather forecasters and the quest for ground truth. Chicago: University of Chicago Press.

de Saint-Laurent, C., Brescó de Luna, I., Awad, S. H., \& Wagoner, B. (2017). Collective memory and social sciences in the post-truth era. Culture \& Psychology, 23(2), $147-155$.

Devadason, R. (2008). To plan or not to plan? Young adult future orientations in two European cities. Sociology - the Journal of the British Sociological Association, 42(6), $1127-1145$.

Dewey, J. (1957). Human nature and conduct: An introduction to social psychology. New York: Modern library.

D'Hondt, F., Van Praag, L., Van Houtte, M., \& Stevens, P. A. J. (2016). The attitude-achievement paradox in Belgium: An examination of school attitudes of ethnic minority students. Acta Sociologica, 59(3), 215-231.

DiMaggio, P., \& Powell, W. W. (1983). The iron cage revisited: Collective rationality and institutional isomorphism in organizational fields. American Sociological Review, 48(2), 147-160.

Domina, T., Conley, A., \& Farkas, G. (2011). The link between educational expectations and effort in the college-for-all era. Sociology of Education, 84(2), 93-112. Duncan, O. D., Haller, A. O., \& Portes, A. (1968). Peer influences on aspirations - reinterpretation. American Journal of Sociology, 74(2), 119-137.

Durkheim, É. (2001). The elementary forms of religious life. Oxford: Oxford University Press.

Elias, N. (2007). An essay on time. Dublin: University College Dublin Press.

Emirbayer, M., \& Mische, A. (1998). What is agency? American Journal of Sociology, 103(4), 962-1023.

Esposito, E. (2013). The structures of uncertainty: Performativity and unpredictability in economic operations. Economy and Society, 42(1), 102-129.

Fastenrath, F., Orban, A., \& Trampusch, C. (2018). From economic gains to social losses: How stories shape expectations in the case of German Municipal Finance. Kölner Zeitschrift Für Soziologie Und Sozialpsychologie, 70, 89-116.

Feliciano, C., \& Rumbaut, R. G. (2005). Gendered paths: Educational and occupational expectations and outcomes among adult children of immigrants. Ethnic and Racial Studies, 28(6), 1087-1118. 
Flaherty, M. G., \& Fine, G. A. (2001). Present, past, and future. Time \& Society, 10(2-3), 147-161.

Frye, M. (2012). Bright futures in Malawi's new dawn: Educational aspirations as assertions of identity. American Journal of Sociology, 117(6), $1565-1624$. Garfinkel, H. (1967). Studies in ethnomethodology. Englewood Cliffs: Prentice Hall.

Gibson, D. R. (2011). Avoiding catastrophe: The interactional production of possibility during the Cuban missile crisis. American Journal of Sociology, 117(2), 361-419.

Giddens, A. (1994). Living in a post-traditional society. In U. Beck, S. Lash, \& A. Giddens (Eds.), Reflexive modernization: Politics, tradition and aesthetics in the modern social order (pp. 56-109). Cambridge: Polity Press.

Gonzales, R. G. (2011). Learning to be illegal: Undocumented youth and shifting legal contexts in the transition to adulthood. American Sociological Review, 76(4), 602-619.

Halawa, M. (2015). New Warsaw Mortgage credit and the unfolding of space and time. Cultural Studies, 29(5-6), 707-732.

Haller, A. O., Otto, L. B., Meier, R. F., \& Ohlendor, G. (1974). Level of occupational aspirations - Empirical analysis. American Sociological Review, 39(1), 113-121.

Hamann, J., \& Suckert, L. (2018). Temporality in discourse: Methodological challenges and a suggestion for a quantified qualitative approach. Forum: Qualitative Social

Research, 19(2). https://doi.org/10.17169/fqs-19.2.2954.

Hanson, S. L. (1994). Lost talent - unrealized educational aspirations and expectations among United-States youths. Sociology of Education, 67(3), 159-183.

Hassard, J. (1990). The sociology of time. Basingstoke: Palgrave Macmillan UK.

Hesse-Biber, S. N., Rodriguez, D., \& Frost, N. A. (2015). A qualitatively driven approach to multimethod and mixed methods research. In S. N. Hesse-Biber, \&

B. Johnson (Eds.), The Oxford handbook of multimethod and mixed methods research inquiry (pp. 3-20). Oxford University Press.

Hills, J. R. (1955). The measurement of levels of aspiration. The Journal of Social Psychology, 41(2), 221-229.

Hirschman, A. O. (1963). Journeys toward progress. Studies of economic policy-making in Latin America. New York: Twentieth Century Fund.

Hirschman, A. O. (1971). A bias for hope; essays on development and Latin America. New Haven: Yale University Press.

Holmes, D. R. (2009). Economy of words. Cultural Anthropology, 24(3), 381-419.

Hölscher, L. (2016). Die Entdeckung der Zukunft. Göttingen: WallsteinVerlag.

Hulme, M. (2008). The conquering of climate: Discourses of fear and their dissolution. Geographical Journal, 174, 5-16.

Jasanoff, S., \& Kim, S.-. H. (2009). Containing the atom: Sociotechnical imaginaries and nuclear power in the United States and South Korea. Minerva, 47(2), 119-146. Kahl, J. A. (1953). Educational and occupational aspirations of "common man" boys. Harvard Educational Review.

Kao, G. (2000). Group images and possible selves among adolescents: Linking stereotypes to expectations by race and ethnicity. Sociological Forum, 15(3), 407-430. Kaplan, S., \& Orlikowski, W. J. (2013). Temporal work in strategy making. Organization Science, 24(4), 965-995.

Karlson, K. B. (2019). Expectation formation for all? Group differences in student response to signals about academic performance. Sociological Quarterly, 60(4), 22. Kolarskabobinska, L. (1994). Social interests and their political representation - Poland in transition. British Journal of Sociology, 45(1), $109-126$.

Koselleck, R. (1979). Vergangene Zukunft: Zur Semantik geschichtlicher Zeiten. Frankfurt: Suhrkamp.

Kuckartz, U. (2014). Qualitative text analysis: A guide to methods, practice and using software. London: Sage.

Laclau, E., \& Mouffe, C. (2001). Hegemony and socialist strategy: Towards a radical democratic politics. London: Verso.

Lê, S., Josse, J., \& Husson, F. (2008). FactoMineR: An R package for multivariate analysis. Journal of Statistical Software, 25(1), 1-18.

Lepenies, P. H. (2008). Possibilism: An approach to problem-solving derived from the life and work of Albert O. Hirschman. Development and Change, 39(3), 437-459. Levy, J. (2017). Capital as process and the history of capitalism. Business History Review, 91(3), 483-510.

Leydesdorff, L., \& Bornmann, L. (2016). The operationalization of "fields" as WoS subject categories in evaluative bibliometrics: The cases of "library and information science" and "science \& technology studies". Journal of the Association for Information Science and Technology, 67(3), 707-714.

Luhmann, N. (1976). The future cannot begin: Temporal structures in modern society. Social Research, 130-152.

Maralani, V. (2014). Understanding the links between education and smoking. Social Science Research, 48, 20-34.

Marini, M. M., \& Fan, P. L. (1997). The gender gap in earnings at career entry. American Sociological Review, 62(4), 588-604.

Mead, G. H. (1932). The philosophy of the present. London: Open Court Publishing Company.

Merton, R. K. (1957). Social theory and social structure (8 edn.). New York: Free Press.

Meyer, J. W., \& Rowan, B. (1977). Institutionalized organizations: Formal structure as myth and ceremony. American Journal of Sociology, 83(2), 340-363.

Mische, A. (2009). Projects and possibilities: Researching futures in action. Sociological Forum, 24(3), 694-704.

Mische, A. (2014). Measuring futures in action: Projective grammars in the Rio+20 debates. Theory and Society, 43(3-4), 437-464.

Nash, K. (2001). The 'cultural turn' in social theory: Towards a theory of cultural politics. Sociology, 35(1), 77-92.

Nerlich, B., \& Halliday, C. (2007). Avian flu: The creation of expectations in the interplay between science and the media. Sociology of Health \& Illness, 29(1), 46-65. Nowotny, H. (1994). Time: The modern and postmodern experience. Malden: John Wiley \& Sons.

Nurmi, J. E. (1987). Age, sex, social-class, and quality of family-interaction as determinants of adolescents future orientation - a developmental task interpretation. Adolescence, 22(88), 977-991.

Nyberg, D., Wright, C., \& Kirk, J. (2018). Fracking the future: The temporal portability of frames in political contests. Organization Studies, 41(2), 175-196. Oksanen, J., Kindt, R., Legendre, P., O'Hara, B., \& Stevens, M. (2007). Vegan: A community ecology package. R Package Version, 1, 8-8.

Olick, J. K., \& Robbins, J. (1998). Social memory studies: From "collective memory" to the historical sociology of mnemonic practices. Annual Review of Sociology, 24 (1), 105-140.

O'Neil, C. (2017). Weapons of math destruction: How big data increases inequality and threatens democracy. London: Penguin Books.

Radkau, J. (2017). Geschichte der Zukunft: Prognosen, Visionen, Irrungen in Deutschland von 1945 bis heute. München: Carl Hanser.

Reith, G. (1999). In search of lost time: Recall, projection and the phenomenology of addiction. Time \& Society, 8(1), 99-117.

Rosa, H. (2013). Social acceleration: A new theory of modernity. New York: Columbia University Press.

Rotter, R. (2016). Waiting in the asylum determination process: Just an empty interlude? Time \& Society, 25(1), 80-101.

Schultz, D. G., \& Ricciuti, H. N. (1954). Level of aspiration measures and college achievement. The Journal of General Psychology, 51(2), 267-275.

Schutz, A. (1972). Collected papers I: The problem of social reality. Dordrecht: Springer.

Sewell, W. H., Jr. (2008). The temporalities of capitalism. Socio-Economic Review, 6(3), 517-537.

Sewell, W. H., Haller, A. O., \& Portes, A. (1969). The educational and early occupational attainment process. American Sociological Review, 34(1), 82-92.

Sewell, W. H., \& Hauser, R. M. (1975). Education, occupation, and earnings. Achievement in the early career. Cambridge: Academic Press.

Sewell, W. H., \& Shah, V. P. (1968). Social class, parental encouragement, and educational aspirations. American Journal of Sociology, 73(5), $559-572$.

Simko, C. (2018). From difficult past to imagined future: Projective reversal and the transformation of ground zero. Poetics, 67, 39-52.

Simmel, G. (1978). The philosophy of money. London: Routledge \& Kegan Paul.

Smith, J. M. (2017). "I’m not gonna be another statistic": The imagined futures of former foster youth. American Journal of Cultural Sociology, 5(1-2), 154-180.

Snee, H., \& Devine, F. (2018). Fair chances and hard work? Families making sense of inequality and opportunity in 21st-century Britain. British Journal of Sociology, 69

(4), 1134-1154.

Snyder, B. H. (2016). The disrupted workplace: Time and the moral order of flexible capitalism. New York: Oxford University Press.

Sorokin, P. A., \& Merton, R. K. (1937). Social time: A methodological and functional analysis. American Journal of Sociology, 42(5), 615-629.

Strauss, A. L. (1993). Continual permutations of action. New York: De Gruyter.

Suckert, L., Beckert, J., \& Fenkner, T. (2020). Corpus of sociological articles studying perceptions of the future. Max Planck Society. https://doi.org/10.17617/3.4x. Swidler, A. (1986). Culture in action: Symbols and strategies. American Sociological Review, 51(2), 273-286.

Tavory, I. (2018). Between situations: Anticipation, rhythms, and the theory of interaction. Sociological Theory, 36(2), 117-133.

Tavory, I., \& Eliasoph, N. (2013). Coordinating futures: Toward a theory of anticipation. American Journal of Sociology, 118(4), 908-942.

Tilly, C. (1994). Remapping memory: The politics of timespace. Minneapolis: University of Minnesota Press.

Urry, J. (2016). What is the future? Cambridge: Polity Press. 
Van Lente, H. (2012). Navigating foresight in a sea of expectations: Lessons from the sociology of expectations. Technology Analysis \& Strategic Management, 24(8), 769-782.

Wagner, P. (2016). Progress: A reconstruction. Cambridge: Polity Press.

Wagner-Pacifici, R. (2009). When futures meet the present. Sociological Forum, 24(3), 705-709.

Wajcman, J. (2015). Pressed for time: The acceleration of life in digital capitalism. Chicago: University of Chicago Press.

Wajcman, J., \& Dodd, N. (2016). The sociology of speed: Digital, organizational, and social temporalities. Oxford: Oxford University Press.

Waller, M. R., \& McLanahan, S. S. (2005). "His" and "Her" marriage expectations: Determinants and consequences. Journal of Marriage and Family, 67(1), 53-67.

Weber, M. (2002). The protest antethic and the "spirit" of capitalism and other writings. New York: Penguin Books.

Wilson, S., \& Milne, E. J. (2016). Visual activism and social justice: Using visual methods to make young people's complex lives visible across "public" and "private" spaces. Current Sociology, 64(1), 140-156.

Ybema, S. (2010). Talk of change: Temporal contrasts and collective identities. Organization Studies, 31(4), 481-503.

Yearley, S. (2009). Sociology and climate change after Kyoto: what roles for social science in understanding climate change? Current Sociology, 57(3), 389-405.

Yilmaz, F. (2012). Right-wing hegemony and immigration: How the populist far-right achieved hegemony through the immigration debate in Europe. Current Sociology, 60(3), 368-381.

Ylijoki, O.-. H., \& Mäntylä, H. (2003). Conflicting time perspectives in academic work. Time \& Society, 12(1), 55-78.

Zerubavel, E. (1981). Hidden rhythms: Schedules and calendars in social life. Chicago: University of Chicago Press.

Jens Beckert is Professor of Sociology and director of the Max Planck Institute for the Study of Societies in Cologne. Recent publication: Imagined Futures. Fictional Expectations and Capitalist Dynamics. Harvard University Press 2016.

Lisa Suckert is Senior Researcher at the Max Planck Institute for the Study of Societies in Cologne. Her main research interests are economic sociology and the temporal order of capitalism. Recent publication: Unravelling Ambivalence: A Field-Theoretical Approach to Moralised Markets. Current Sociology 66, 5, 682-703 (2018). 